\title{
Evaluation of the Nicotinic Acetylcholine Receptor-Associated Proteome at Baseline and Following Nicotine Exposure in Human and Mouse Cortex
}

\author{
(1)Tristan D. McClure-Begley, ${ }^{1,2,3}$ Irina Esterlis, ${ }^{1}$ Kathryn L. Stone, ${ }^{4}{ }^{1}$ TuKiet T. Lam, ${ }^{4,5}$ Sharon R. Grady, ${ }^{2}$ \\ (1) Christopher M. Colangelo, ${ }^{4,5}$ Jon M. Lindstrom, ${ }^{6}$ Michael J. Marks, ${ }^{2,7}$ and ${ }^{10}$ Marina R. Picciotto ${ }^{1,4}$
}

\section{DOI:http://dx.doi.org/10.1523/ENEURO.0166-16.2016}

${ }^{1}$ Department of Psychiatry, Yale University School of Medicine, New Haven, Connecticut $06508,{ }^{2}$ Institute for Behavioral Genetics, University of Colorado, Boulder, Colorado 80303, ${ }^{3}$ Department of Molecular, Cellular and Developmental Biology, University of Colorado, Boulder, Colorado 80309, ${ }^{4}$ W.M. Keck Biotechnology Resource Laboratory, Yale University School Medicine, New Haven, Connecticut 06509, ${ }^{5}$ Department of Molecular Biophysics \& Biochemistry, Yale University, New Haven, Connecticut 06520, 'ㄹepartment of Neuroscience, Medical School of the University of Pennsylvania, Philadelphia, Pennsylvania 19104, and ${ }^{7}$ Department of Psychology and Neuroscience, University of Colorado, Boulder, Colorado 80309

\begin{abstract}
Nicotinic acetylcholine receptors (nAChRs) support the initiation and maintenance of smoking, but the long-term changes occurring in the protein complex as a result of smoking and the nicotine in tobacco are not known. Human studies and animal models have also demonstrated that increasing cholinergic tone increases behaviors related to depression, suggesting that the nAChR-associated proteome could be altered in individuals with mood disorders. We therefore immunopurified $\mathrm{nAChRs}$ and associated proteins for quantitative proteomic assessment of changes in protein-protein interactions of high-affinity $n A C h R s$ containing the $\beta 2$ subunit $(\beta 2 *-n A C h R s)$ from either cortex of mice treated with saline or nicotine, or postmortem human temporal cortex tissue from tobacco-exposed and nonexposed individuals, with a further comparison of diagnosed mood disorder to control subjects. We observed significant effects of nicotine exposure on the $\beta 2 *$-nAChR-associated proteome in human and mouse cortex, particularly in the abundance of the nAChR subunits themselves, as well as putative interacting proteins that make up core components of neuronal excitability (Na/K ATPase subunits), presynaptic neurotransmitter release (syntaxins, SNAP25, synaptotagmin), and a member of a known nAChR protein chaperone family (14-3-3̧). These findings identify candidate-signaling proteins that could mediate changes in cholinergic signaling via nicotine or tobacco use. Further analysis of identified proteins will determine whether these interactions are essential for primary function of $n A C h R s$ at presynaptic terminals. The identification of differences in the nAChR-associated proteome and downstream signaling in subjects with various mood disorders may also identify novel etiological mechanisms and reveal new treatment targets.
\end{abstract}

Key words: addiction; cortex; depression; nicotine; nicotinic acetylcholine receptors; proteomics

\section{Significance Statement}

Nicotinic acetylcholine receptors (nAChRs) are ligand-gated ion channels responsible for rapid excitatory acetylcholine signaling, which modulate numerous circuits involved in complex behaviors. In addition, nAChRs are the primary targets for the reinforcing effects of nicotine in tobacco products. Proteins associated with nAChRs are critical for receptor trafficking, localization, and function. Identifying the core elements of the nAChR-associated proteome that are conserved across human and mouse brain is essential for understanding how these receptors are regulated, and how their functions and interactions are altered by long-term exposure to nicotine. 


\section{Introduction}

Individuals who smoke have significantly higher numbers of high-affinity nicotinic acetylcholine receptors (nAChRs) compared to nonsmokers, as measured in both postmortem brain studies (Breese et al., 1997) and SPECT imaging studies with a radiotracer specific for $\mathrm{nAChRs}$ containing the $\beta 2$ subunit $(\beta 2 *-\mathrm{nAChRs}$; Staley et al., 2006). This upregulation appears to be due primarily to the nicotine in tobacco, since rodent studies demonstrate that long-term exposure to nicotine alone results in a similar upregulation of $\beta 2 *-\mathrm{nAChRs}$ in brain (Marks et al., 1992). While this change in receptor number can alter signaling through nAChRs (Buisson and Bertrand, 2001; Govind et al., 2012), the effect of nicotine treatment and upregulation on the associated proteome is not known. Identifying the complex associated with upregulated nAChRs would be helpful in understanding both the basic biology of the nAChR system, as well as the consequences of smoking on $\mathrm{nAChR}$-induced intracellular signaling. Comparison of the $\mathrm{nAChR}$-associated proteome in human smokers versus rodents exposed to nicotine is also important to identify molecular changes selective for nicotine alone, rather than the $\sim 4000$ other constituents of tobacco smoke. Further, the identification of the changes in the nAChR-associated proteome as a result of nicotine exposure could provide insights into the mechanisms underlying $\mathrm{nAChR}$ upregulation, as well as determining whether nicotine-mediated upregulation alters the downstream signaling of these receptors. Finally, comparison of the human and rodent $\mathrm{nAChR}$-associated proteome at baseline could identify conserved signaling pathways that important for ongoing smoking behavior and other disorders associated with changes in $\mathrm{nAChR}$ signaling.

Among disorders associated with smoking, mood disorders (MDs) are of particular interest because of the high

Received June 15, 2016; accepted July 29, 2016; First published August 03, 2016.

The authors declare no competing financial interests.

Author contributions: T.D.M.-B., M.J.M., and M.R.P. designed research; T.D.M.-B., K.L.S., T.T.L., S.R.G., C.M.C., and M.J.M. performed research; I.E. and J.M.L. contributed unpublished reagents/analytic tools; T.D.M.-B., K.L.S., T.T.L., and C.M.C. analyzed data; T.D.M.-B. and M.R.P. wrote the paper.

This research was funded by Grants $M H-077681$ and DA-14241 (to M.R.P.), K01-MH-092681 (to I.E.), DA-018343 (National Institute on Drug Abuse Proteomics Center at Yale University), and UL1-RR-024139 (Yale Clinical and Translational Science Award) from the National Institutes of Health (NIH); and by the State of Connecticut, Department of Mental Health and Addiction Services. T.D.M.-B. was supported by NIH Grant T32-MH-014276. M.J.M. and S.R.G. were supported by NIH Grants DA-003194 and DA-015663. J.M.L. was supported by NIH Grant NS-11323.

Acknowledgments: We thank Dr. Gustavo Turecki of McGill University for providing the brain samples, the W.M. Keck Biotechnology Resource Facility at the Yale School of Medicine for the SRM analysis of tissue cotinine content, and Megan Miller for critical feedback on the manuscript.

Correspondence should be addressed to Marina R. Picciotto, Department of Psychiatry, Yale University School of Medicine, 34 Park Street, 3rd Floor Research, New Haven, CT 06508. E-mail: marina.picciotto@yale.edu.

DOI:http://dx.doi.org/10.1523/ENEURO.0166-16.2016

Copyright (C) 2016 McClure-Begley et al.

This is an open-access article distributed under the terms of the Creative Commons Attribution 4.0 International, which permits unrestricted use, distribution and reproduction in any medium provided that the original work is properly attributed. comorbidity reported (Lerman et al., 1996; Laje et al., 2001; Mineur and Picciotto, 2009) and because several lines of evidence implicate the dysfunction of the cholinergic system in depressive states (for review, see Mineur and Picciotto, 2010; Philip et al., 2010). Animal and human studies suggest that increased ACh activity can induce symptoms of depression, whereas decreased cholinergic activity may be associated with mania (Dilsaver, 1986; Dilsaver and Coffman, 1989). Consistent with challenge studies using a cholinesterase inhibitor to increase nAChR occupancy (Esterlis et al., 2013), imaging studies suggest that brain ACh levels may be higher in individuals with major depressive or bipolar disorder when they are actively depressed (Saricicek et al., 2012; Hannestad et al., 2013). With respect to nAChRs, decreasing the activity of $\beta 2 *-n A C h R s$ using molecular genetics, pharmacological antagonism, or partial agonism can alter behavior in tests of antidepressant efficacy (Caldarone et al., 2004; Rabenstein et al., 2006; Mineur et al., 2007, 2009). Overall $\mathrm{nAChR}$ signaling may be altered in individuals with depressive disorders, suggesting that it could be important to identify any potential differences in the functional regulation of $\beta 2 *-\mathrm{nAChRs}$ and protein-protein interactions in patients with affective disorders.

In the current study, we took a dual approach to identify changes in the nAChR-associated proteome with nicotine exposure and to determine whether any changes were also apparent in individuals with a mood disorder. We obtained postmortem tissue from the temporal cortex of human subjects and used tissue cotinine content as a determinant of tobacco use to determine whether there was any difference in the nAChR-associated proteome as a function of receptor number. (Note that we use "tobacco use" rather than "smoker" since it is not possible to discriminate between modes of tobacco use from brain metabolite levels). Among the human subjects, we evaluated cortical tissue from both healthy control subjects and matched individuals with a mood disorder diagnosis to identify any differences in receptor number or response to smoking. In addition, we exposed mice with differing levels of high-affinity nAChRs to nicotine in the long term to identify changes in the associated proteome that do or do not scale with nAChR number to determine which smoking-induced changes in human tissue can be attributed to the nicotine in tobacco. These results are the first to compare human and mouse nAChR-associated proteins, and the findings identify conserved proteins in the $\beta 2 *-n A C h R$ interactome and the effects of nicotine exposure that are valid to explore with other models.

\section{Materials and Methods}

\section{Human temporal cortex tissue collection}

Human temporal cortex samples were obtained from the Douglas Brain Bank as frozen tissue sections, ranging from 0.29 to $1.03 \mathrm{~g}$ wet weight of tissue. Visual inspection of each section indicated approximately equivalent amounts of gray and white matter per section. All tissue samples were numbered by the supplier, with diagnosis (major depressive, bipolar, mood disorder not otherwise specified, or no mood disorder) and cause of death as the 
only additional information. Experimental results were not sorted by diagnosis until after results were obtained; experimenters were blind to the groups during data collection.

\section{Mice}

Wild-type mice and mice carrying genetic deletion of the $\beta 2 \mathrm{nAChR}$ subunit (Picciotto et al., 1995, 1998) or the $\alpha 4$ nAChR subunit (Ross et al., 2000) were used for these studies. The animals used were wild type $\left(\beta 2^{+/+}\right)$, heterozygous $\left(\beta 2^{+/-}\right), \alpha 4 / \beta 2$ double-heterozygous $\left(\alpha 4^{+/}\right.$ $\left.-\beta 2^{+/-}\right)$, and knock-out $\left(\beta 2^{-/-}\right)$mice. Mice were bred and maintained in the animal colonies at the University of Colorado and Yale University. Female mice were used for this study because females are more resilient to chronic nicotine administration (Hatchell and Collins, 1980) and were housed in groups of no more than five same-sex littermates per cage, on a $12 \mathrm{~h}$ light/dark cycle with ad libitum access to food and water. All protocols involving the use of live animals were approved by and followed the guidelines of the institutional animal care and use committees of the University of Colorado and Yale University.

\section{Surgery and long-term nicotine treatment}

Mice were fitted with jugular catheters essentially as described previously (Marks et al., 2011), with minor modifications. Briefly, mice were anesthetized with an intraperitoneal injection of ketamine/xylazine $(100 / 8 \mathrm{mg} / \mathrm{kg})$ and a small incision $(<1 \mathrm{~cm})$ was made above the right clavicle to access the superficial aspect of the jugular vein. A small catheter (inner diameter, $0.51 \mathrm{~mm}$; outer diameter, $0.94 \mathrm{~mm}$ ) made of medical-grade silastic tubing and filled with sterile saline solution was inserted into the exposed vein and anchored in position with two surgical silk sutures. The catheter was passed under the skin through a second small $(<1 \mathrm{~cm})$ incision made in the midthoracic region of the skin and was attached to a stainless steel post anchored under the skin with veterinary adhesive. Incisions were cleaned with $0.1 \%$ iodine in ethanol and closed with veterinary adhesive. Mice were given an intraperitoneal injection of buprenorphine (0.1 $\mathrm{mg} / \mathrm{kg}$ ) following surgery and were allowed to recover in warm $\left(37^{\circ} \mathrm{C}\right)$ individual cages. For long-term infusion, mice were housed individually, and the jugular catheter was attached to a $1 \mathrm{ml}$ syringe pump and infused with saline at a rate of $35 \mu \mathrm{l} / \mathrm{h}$ for $48 \mathrm{~h}$. Vehicle control mice received sterile saline, and nicotine-treated animals received $4 \mathrm{mg} / \mathrm{kg} / \mathrm{h}$ nicotine (free base, neutralized with $\mathrm{HCl}$ ) for a total of $10 \mathrm{~d}$. On the last day of nicotine treatment, mice were detached from the syringe pump and allowed to clear the nicotine for $2 \mathrm{~h}$. Mice were killed by cervical dislocation, and the brain was rapidly removed and placed on an ice-cold surface for dissection. Each brain was dissected, and the cortex was frozen at $-80^{\circ} \mathrm{C}$ until analysis.

\section{$\left[{ }^{125} \mid\right]$-Epibatidine binding}

Quantification of high-affinity nAChR binding sites in brain tissue was performed essentially as described previously (Hannestad et al., 2013) with minor modifications. Briefly, a small prism of tissue was removed from the large frozen section by dissection on an ice-cold surface with a sterile scalpel. The excised tissue was placed immediately in $0.25 \mathrm{ml}$ ice-cold $0.1 \times$ phosphate buffer $(\mathrm{PB} ; 12.8 \mathrm{~mm}$ $\mathrm{NaCl}, 0.24 \mathrm{~mm} \mathrm{KCl}, 0.32 \mathrm{~mm} \mathrm{CaCl}, 0.12 \mathrm{~mm} \mathrm{KH}_{2} \mathrm{PO}_{4}$, $0.12 \mathrm{~mm} \mathrm{MgSO}_{4} .7 \mathrm{H}_{2} \mathrm{O}, 2.5 \mathrm{~mm}$ HEPES hemi-Na, pH7.5). Samples were homogenized by hand in a glass/Teflon tissue grinder and diluted to a final volume of $0.5 \mathrm{ml}$ in $0.1 \times \mathrm{PB}$. The tissue homogenate was centrifuged at $10,000 \times \mathrm{g}$ at $4^{\circ} \mathrm{C}$ for $20 \mathrm{~min}$, and the supernatant was discarded. The tissue pellet was resuspended in $0.5 \mathrm{ml}$ of $0.1 \times \mathrm{PB}$ and centrifuged for $20 \mathrm{~min}$ at $10,000 \times g$ at $4^{\circ} \mathrm{C}$. This wash step was repeated a total of three times in order to ensure the removal of substances that could compete with [ $\left.{ }^{125}\right]$ l-epibatidine binding (i.e., nicotine, ACh). For ligand binding to particulate fractions, $10 \mu \mathrm{l}$ aliquots of tissue homogenate were added to wells of 96-well plates containing 200 pM [ $\left.{ }^{125} \mathrm{I}\right]$-epibatidine as the final concentration (Whiteaker et al., 2000). Nonspecific binding was assessed in the presence of $100 \mu \mathrm{m}$ cytisine. The protein content of each sample was determined using the method of Lowry et al. (1951).

\section{Immunopurification of $\boldsymbol{\beta 2} *$-nAChRs}

Purification of $\beta 2 *-\mathrm{nAChRs}$ with mAb295-coupled M270 Dynabeads from mouse and human cortical tissue samples was conducted essentially as described previously (McClure-Begley et al., 2013), with minor modifications. For the mouse cortex samples, dissected cortices (both hemispheres) from two mice were pooled to create one homogenate for immunoprecipitation (IP); human samples were used as is, and the volume of homogenization buffer was adjusted to equal 4 volumes based on the total wet weight of the tissue. Briefly, brain tissue sections were homogenized by hand with 17 strokes in a glass/Teflon tissue grinder with 4 volumes of ice-cold PBS $(\mathrm{pH} 8.0)$, and placed on ice. To each tissue homogenate, dithiobis[succinimidyl propionate] [DSP (also called Lamont's Reagent); $12 \AA$ linker span; 10 mM in DMSO] was added to a final concentration of $1 \mathrm{~mm}$ to stabilize labile interactions prior to detergent extraction. Tissue homogenates were incubated on ice for $45 \mathrm{~min}$ with DSP prior to the addition of Tris to a final concentration of $10 \mathrm{~mm}$ to quench the crosslinking reaction. Samples were centrifuged at $10,000 \times g$ at $4^{\circ} \mathrm{C}$ for $20 \mathrm{~min}$, and the supernatant was collected and frozen at $-20^{\circ} \mathrm{C}$, and the pellet was washed by resuspension in TBS before being centrifuged again. The washed pellet was resuspended in $2 \mathrm{ml}$ of extraction buffer (EB; in mM: $121.9 \mathrm{NaCl}, 2.68 \mathrm{KCl}, 10.14$ $\mathrm{Na}_{2} \mathrm{HPO}_{4}, 1.76 \mathrm{KH}_{2} \mathrm{PO}_{4}, 5$ EDTA, 5 EGTA, $5 \mathrm{NaF}, 0.1$ $\mathrm{Na}_{3} \mathrm{VO}_{4}, 1.0 \mathrm{PMSF}, 10 \mu \mathrm{g} / \mathrm{ml}$ each of aprotonin, prepstatin $\mathrm{A}$, leupeptin, 0 and $6 \%$ Triton $\mathrm{X}-100, \mathrm{pH} 7.4$ ) and incubated for $30 \mathrm{~min}$ with gentle rotation at room temperature. The extract was clarified by centrifugation at 10,000 $\times g$ at $4^{\circ} \mathrm{C}$ for $20 \mathrm{~min}$, and the supernatant was collected. A $100 \mu \mathrm{l}$ aliquot of clarified extract was taken at this point to quantify total extracted nAChR content with [ $\left.{ }^{125} \mathrm{I}\right]$ epibatidine binding, as described below. The remaining extract was added to $5 \mathrm{ml}$ of polystyrene culture tubes containing a volume of mAb295-Dynabeads equivalent to $50 \%$ of the input volume and incubated with gentle rotation at $4^{\circ} \mathrm{C}$ overnight. The following morning, sample 
tubes were placed on a magnetic stand to separate the mAb295 beads, and a $100 \mu \mathrm{l}$ aliquot of the supernatant was collected to assess nAChR capture efficiency. For the quantification of nAChR immunopurification, $20 \mu \mathrm{l}$ aliquots of input and post-IP tissue lysate were labeled with 200 pм [ $\left.{ }^{125} \mathrm{I}\right]$-epibatidine overnight at $4^{\circ} \mathrm{C}$, and protein precipitated by $50 \mu \mathrm{l}$ of $40 \% \mathrm{~W} / \mathrm{v}$ polyethylene glycol (PEG) added to each well. PEG-precipitated binding sites were captured on filter membranes as for the particulate binding studies. The depletion of binding sites was used to estimate receptor content of each sample post-elution.

\section{Sample preparation and protein identification by liquid chromatography-tandem mass spectrometry}

Dynabeads carrying mAb295-captured nAChRs and bound proteins were washed two times with $1 \mathrm{ml}$ of PBS $\left(137 \mathrm{~mm} \mathrm{NaCl}, 27 \mathrm{~mm} \mathrm{KCl}, 100 \mathrm{~mm} \mathrm{Na} \mathrm{HPO}_{4}, 18 \mathrm{~mm}\right.$ $\mathrm{KH}_{2} \mathrm{PO}_{4}$, pH 7.5) containing $0.01 \%$ Tween-20, and one time with PBS prior to elution with $0.5 \mathrm{ml}$ of $0.1 \mathrm{M} \mathrm{NH}_{4} \mathrm{OH}$ and $1 \mathrm{~mm}$ EDTA, $\mathrm{pH}$ 10.0. Elution was performed twice, and eluates were pooled prior to lyophilization in a Thermo Savant SPD1010 Speedvac. Eluted proteins were reduced, alkylated, and digested as described previously (McClure-Begley et al., 2013). Mouse cortex samples were labeled in an eight-plex iTRAQ labeling scheme, and peptide sequencing was performed on an ABSciex 5600 triple- time-of-flight mass spectrometer, with iTRAQ quantitation in ProteinPilot software, as has been described (McClure-Begley et al., 2013). For the human temporal cortex samples, the eluted protein pellet was redissolved in $30 \mu \mathrm{l}$ of $8 \mathrm{M}$ urea/ $0.4 \mathrm{M}$ ammonium bicarbonate, $\mathrm{pH}$ 8.0. The addition of $3 \mu \mathrm{l}$ of $45 \mathrm{~mm}$ DTT was followed by vortexing, and samples were then incubated at $37^{\circ} \mathrm{C}$ for $20 \mathrm{~min}$. Reduced samples were cooled to room temperature and alkylated with $3 \mu \mathrm{l}$ of $100 \mathrm{~mm}$ iodoacetamide for $20 \mathrm{~min}$ in the dark. Water $(74 \mu \mathrm{l})$ was added to dilute the sample prior to trypsin digestion (10 $\mu l, 0.5 \mathrm{mg} / \mathrm{ml}$ ) at $37^{\circ} \mathrm{C}$ overnight. Samples were desalted on a Macrospin cartridge (Nest Group), and eluent was dried in a Speedvac. The pellet was resuspended in $10 \mu \mathrm{l}$ of $70 \%$ formic acid and $40 \mu \mathrm{l}$ of $50 \mathrm{~mm}$ sodium PB. Equal peptide amounts were aliquoted into glass vials for injection.

Proteomic analysis was performed using a label-free quantification (LFQ) method on an Orbitrap Elite equipped with a Waters Symmetry C18 $(180 \mu \mathrm{m} \times 20 \mathrm{~mm})$ trap column and a $1.7 \mu \mathrm{m}, 75 \mu \mathrm{m} \times 250 \mathrm{~mm}$ nanoAcquity ultra high-performance liquid chromatography (UPLC) column $\left(35^{\circ} \mathrm{C}\right)$. Trapping was performed using $99 \%$ Buffer A (99.9\% water, $0.1 \%$ formic acid) and peptide separation with a linear gradient of solvent $A(0.1 \%$ formic acid in water) and solvent B ( $0.075 \%$ formic acid in acetonitrile) over $90 \mathrm{~min}$, at a flow rate of $300 \mathrm{nl} / \mathrm{min}$. MS spectra were acquired in the Orbitrap using a $1 \mu \mathrm{m}$ scan and a maximum injection time of $900 \mathrm{~ms}$ followed by three datadependant MS/MS acquisitions in the ion trap (with precursor ions threshold of $>3000$ ). The total cycle time for both MS and MS/MS acquisition was $2.4 \mathrm{~s}$. Peaks targeted for MS/MS fragmentation by collision-induced dissociation were first isolated with a $2 \mathrm{Da}$ window followed by normalized collision energy of $35 \%$. Dynamic exclusion was activated where former target ions were excluded for $30 \mathrm{~s}$.

Feature extraction, chromatographic/spectral alignment, data filtering, and statistical analysis were performed using Nonlinear Dynamics Progenesis LC-MS software (www.nonlinear.com). The raw data files were imported into the program, a sample run was chosen as a reference (usually at or near the middle of all runs in a set), and all other runs were automatically aligned to that run in order to minimize retention time (RT) variability between runs. All runs were selected for the detection of peptides with an automatic detection limit for signal-to-noise ratio of 3. Features within RT ranges of $0-25$ min and 110-120 min were filtered out (these are outside the range of the peptide elution profile), as were features with a charge of $\geq 7$. A normalization factor was then calculated for each run to account for differences in sample load between injections. The experimental design was set up to group multiple injections from each run. The algorithm then calculated and tabulated the raw and normalized abundances, the maximum fold changes and the ANOVA values for each feature in the dataset. The corresponding MS and MS/MS spectra for the features were exported as a Mascot generic file (.mgf) for database searching to perform protein identification. The .mgf files created by the Progenesis LCMS were searched in-house using the Mascot Search Algorithm (version 2.2.0). The data were searched using the Swiss protein database along with the following search parameters: enzyme, trypsin; variable modifications, carbamidomethyl (Cys), oxidation (Met), and alkylated DSP crosslinker-modified lysine $\left(\mathrm{C}_{10} \mathrm{H}_{19} \mathrm{~N}_{2} \mathrm{O}_{3} \mathrm{~S}_{2}\right)$; peptide mass tolerance, $\pm 20 \mathrm{ppm}$; fragment mass tolerance, $\pm 0.6 \mathrm{Da}$; charge, +7 ; maximum missed cleavages, 3 ; decoy, yes; and instrument type, ESI-TRAP. The resulting search was exported as an .xml file and read into the Progenesis LC-MS software, where search hits, with at least $95 \%$ confidence, were matched to corresponding features (precursor ions and abundances). Features/peptides with nonconflicting identification match were used to provide relative quantification of protein expression. The identification of peptides/proteins and quantitative values across the various comparisons were exported as a .csv file, and further downstream data analyses were performed. The means of normalized abundances for proteins identified in three technical replicates for each tissue sample were used in subsequent analyses.

\section{Cotinine determination from brain tissue lysate by liquid chromatography-tandem mass spectrometry}

Following detergent extraction from tissue homogenates and immunopurification of $\beta 2 *$-nAChR complexes with mAb295-coupled Dynabeads, the clarified lysate was frozen at $-20^{\circ} \mathrm{C}$. The lysate was thawed, and a $200 \mu \mathrm{l}$ aliquot of each sample was subjected to organic extraction according to published methods (Massadeh et al., 2009) with minor modification. Briefly, the clarified tissue lysate was alkalized with $50 \mu \mathrm{l}$ of $1 \mathrm{M} \mathrm{NaOH}$ and mixed with $2.5 \mathrm{ml}$ of $1: 1$ dichloromethane/hexanes in a glass test tube and vortexed vigorously. The mixture was centrifuged for $10 \mathrm{~min}$ at $5000 \times g$ at room temperature, and 
the upper organic layer was removed and placed in a clean borosilicate glass tube, then dried under a gentle stream of nitrogen at room temperature. Samples were reconstituted in $100 \mu \mathrm{l}$ of $0.1 \%$ formic acid in water, and $10 \mu$ of each sample was used per injection for analysis.

All liquid chromatography-tandem mass spectrometry (LC-MS/MS) identifications of cotinine were performed on an ABSciex 4000 QTrap Mass Spectrometer in positive ion mode coupled to a PerkinElmer Flexar FX-15 UPLC unit. For chromatography, solvent A was 99.9\% water and $0.1 \%$ formic acid, and solvent B was $99.9 \%$ acetonitrile and $0.1 \%$ formic acid. The elution gradient was as follows: $98 \%$ solvent A, $2 \%$ solvent B from 0 to $1.8 \mathrm{~min} ; 98 \%$ solvent $B, 2 \%$ solvent $A$ from 1.8 to $2.8 \mathrm{~min}$; and $98 \%$ solvent $A, 2 \%$ solvent $B$ from 2.9 to $6.0 \mathrm{~min}$. A selected reaction monitoring (SRM) method was developed for the quantification of cotinine present in the sample using an isotopically coded analytical standard (d-cotinine; Cerilliant Corporation). As described previously (Jacob et al., 2011), the cotinine parent ion had a mass-to-charge ratio $(\mathrm{m} / \mathrm{z})$ of 177.12 at charge +1 and yielded a specific transition with major product ions of an $\mathrm{m} / \mathrm{z}$ values of 80.03 and 98.02. Standard curves showed that intensities of both major product ions were linear with respect to injected cotinine $>9.5 \mathrm{ng} / \mu \mathrm{l}$. Cotinine abundances for each transition from replicate injections were averaged and normalized to the total wet weight of each tissue sample in order to yield units of nanograms per gram tissue to determine nicotine use status.

\section{Data analysis}

SigmaPlot 13.0 and SPSS 23 (2015) were used for data organization and statistical analysis. All ligand binding data are reported in specific femtomoles/milligram protein. For proteins identified with LC-MS/MS, we took the sum of the normalized protein abundance for all proteins scoring above the $95 \%$ false discovery rate (FDR) cutoff from three technical replicates per sample and generated arithmetic means that were then log2 transformed to yield a continuous variable with a normal distribution (Smits et al., 2013). Linear regression analysis was performed using a Pearson's product moment correlation coefficient $(r)$ as an indicator of significant positive correlations. Normalization using the calculated abundance of the $\beta 2$ nAChR subunit (target of the IP) in each sample as the denominator was performed, and ratios relative to control conditions were compared to assess alterations in associated proteins per unit of $n A C h R$.

Mouse cortex ITRAQ data were processed as has been described previously (McClure-Begley et al., 2013). Briefly, mean values of the reporter ion peak areas for every protein identified above the FDR cutoff were divided by the mean value for the control condition $\left(\beta 2^{+/+}\right.$, saline) for each set and then log2 transformed to yield normalized protein expression ratios. Significant effects of nicotine exposure and mouse genotype (for the mouse samples) or mood disorder diagnosis and nicotine use (human samples) were determined with ANOVA, Holm-Sidak test, or Student's $t$ test, where appropriate as determined by the nature of the experiment, with a $95 \%$ confidence interval. A general linear model (GLM) split by protein identification with multiple univariate comparisons was used to determine whether levels of individual human brain proteins [a normally distributed (log2 fold change) continuous response variable] that vary over multiple categorical predictor variables (nicotine, MD, both, or neither) differed in representation compared with the control condition (where the intercept is the mean of the no-nicotine exposure, no-MD diagnosis values). This was only possible for human cortical samples that were run using LFQ, in which there is a discrete interval measurement for every group. Mouse samples were run on ITRAQ in which every eight-plex experiment uses one channel as the control value, which is convoluted into the variance of the other seven reporter ion channels. Thus, the mouse GLM does not include a discrete value for the control group, since reintroducing the control group drags the regression to the origin and biases the estimates of significance.

Data are reported as mean \pm SEM, with error terms specifically reported for each value.

\section{Results}

\section{Effects of smoking and mood disorder diagnosis on nAChR number measured with $\left[{ }^{125} \mathrm{I}\right]$-epibatidine binding}

We measured high-affinity $\left[{ }^{125} \mathrm{l}\right]$-epibatidine binding to particulate fractions in order to determine any effects of smoking status and mood disorder diagnosis on $\mathrm{nAChR}$ number in human temporal cortex. High levels of $\alpha 4 \beta 2 *-$ nAChRs, the subtype upregulated by concentrations of nicotine typically encountered by smokers (Teaktong et al., 2004), are found in mammalian cortex (Zoli et al., 1998). Smoking status was not included with human tissue samples, so in order to group samples appropriately, we examined the cotinine content of each sample using an SRM LC-MS/MS method with a deuterated cotinine standard. Samples were grouped according to cotinine content and $\alpha 4 \beta 2 *-n A C h R$ expression, with "nicotine users" considered as those samples with $>15$ ng cotinine/g wet tissue weight. Cotinine levels present in tissue did not correlate linearly with $\left[{ }^{125} \mathrm{l}\right]$-epibatidine binding sites $\left(r^{2}=\right.$ 0.33), indicating that the postmortem tissue content of the major nicotine metabolite is useful principally for ordinal assignment of nicotine use (nicotine user or nonuser), and cannot be used to further discriminate "heavy/moderate/ light" nicotine users. Based on these criteria, there were nine nicotine users and nine nonusers. Consistent with the high comorbidity between smoking and depression, the incidence of nicotine exposure was higher in individuals with a diagnosed mood disorder (six of nine were nicotine users) compared with individuals with no psychiatric diagnosis (three of nine were nicotine users). We observed a significant effect of cotinine level, our empirically determined tobacco use criterion, on nAChR number, as measured by epibatidine binding in homogenates (two-way ANOVA with Holm-Sidak multiple comparisons: $F_{(1,17)}=$ $9.794, p=0.007)$. Analysis revealed no significant effect of mood disorder diagnosis on $\mathrm{nAChR}$ number $\left(F_{(1,17)}=\right.$ $0.224, p=0.673$ ) or an interaction of nicotine $\times$ mood disorder $\left(F_{(1,17)}=0.04, p=0.836\right)$ measured by equilib- 
A

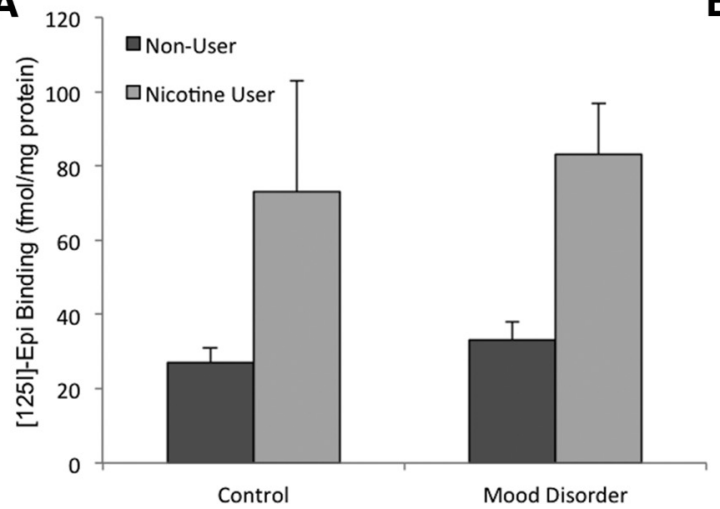

$\mathbf{B}$

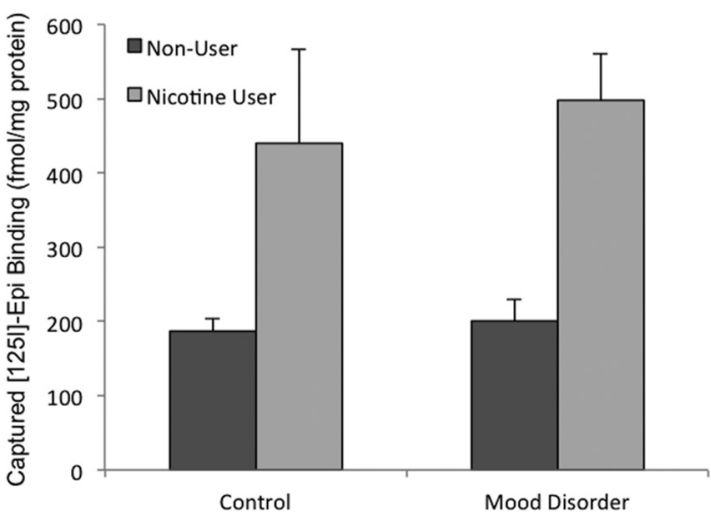

Figure 1. Effects of nicotine use and mood disorder on total high-affinity $\left[{ }^{125} \mathrm{l}\right]$-epibatidine binding in cell membranes from human temporal cortex samples. $\boldsymbol{A}$, Nicotine use, determined by tissue cotinine content, has a significant effect on the number of total $\left[{ }^{125} \mathrm{l}\right]$-epibatidine binding sites (two-way ANOVA with Holm-Sidak multiple comparisons: $F_{(1,17)}=9.794, p=0.007$ ), while mood disorder does not have an appreciable effect on the expression of high-affinity nAChRs in the cortex $\left(F_{(1,17)}=0.224, p=0.673\right)$. $\boldsymbol{B}$, $\beta 2 *-n A C h R$ capture was evaluated by $\left[{ }^{125} \mathrm{l}\right]$-epibatidine binding following immunoprecipitation from human temporal cortex using mAb295-M270 Dynabeads. Error bars represent standard error of the mean.

rium ligand binding (Fig. 1A), which is in agreement with previous assessments of $\mathrm{nAChR}$ number in postmortem human cortical tissue from individuals with major depression or bipolar disorder (Saricicek et al., 2012; Hannestad et al., 2013).

\section{Immunoprecipitation of $\boldsymbol{\beta} 2 *-\mathrm{nAChRs}$ from human temporal cortex and identification of specific interacting proteins by tandem mass spectrometry} Following the extraction of $\mathrm{nAChR}$ complexes from human brain tissue, we quantified specific mAb295 immunocapture of $\beta 2 *-n A C h R s$ by measuring total $\left[{ }^{125} \mathrm{l}\right]$ epibatidine binding sites in the solubilized tissue extract before and after incubation with mAb295-Dynabeads. In human temporal cortex samples, the recovery of $\beta 2 \%-$ $n A C h R s$ using mAb295-Dynabeads was $74.5 \pm 7.6 \%$ of input across all samples, with no effect of either smoking status or mood disorder diagnosis ( $t$ test, $p=0.32, t=$ -1.017, df = 16). In mouse cortex samples, despite fractional differences in the percentage of upregulation induced by long-term nicotine exposure as a function of genotype, capture efficiency was $60.9 \pm 3.1 \%$ of input across the samples, with no significant difference in capture efficiency between the saline control and groups receiving long-term nicotine treatment $(t$ test, $p=0.06$, $t=-2.108$, df $=10$ ), indicating that the immobilized mAb295 performed equally well across the samples regardless of differences in $\mathrm{nAChR}$ abundance. As expected based on epibatidine binding levels in homogenates and previously published studies, we observed a significant effect of nicotine use on the amount of $\beta 2 *-$ nAChR present in each sample (Fig. 1B); however, no significant effect of mood disorder diagnosis or nicotine $X$ mood disorder interaction was identified (two-way ANOVA: main effect, nicotine use: $F_{(1,17)}=18.002, p<$ 0.0009 ; main effect, mood disorder: $F_{(1,17)}=0.236, p=$ 0.634; interaction: $\left.F_{(1,17)}=0.06, p=0.813\right)$.

Transgenic mice lacking expression of $\alpha 4$ and $\beta 2$ $\mathrm{nAChR}$ subunits have been used previously to establish a gene dose-dependent linear relationship between $\alpha 4 \beta 2 *-$ nAChRs and their putative associated proteins from whole mouse brain samples using an immunocapture protocol with iTRAQ-labeled peptides for quantitative proteomics (McClure-Begley et al., 2013). Such an approach used nAChR subunit heterozygous and knock-out mice to vary the abundance of nAChRs reliably and to examine relative changes in associated proteins with linear regressions to enhance confidence in identifying interacting proteins. In the human tissue samples used in this study, we observed significant variation in the total nAChR content of each sample, partially due to inherent variability, but also because of the impact of nicotine use. The measured abundance of the $\beta 2 \mathrm{nAChR}$ subunit (target of the (P) as well as the abundance of $\alpha 4 \mathrm{nAChR}$ subunits measured by LFQ proteomics correlate extremely well with the calculated nAChR content of each sample obtained by the depletion of specific [ $\left.{ }^{125} \mathrm{l}\right]$ epibatidine binding from tissue extracts (femtomoles vs $\beta 2$-LFQ: $r^{2}=0.89$; femtomoles vs $\alpha 4$-LFQ: $r^{2}=0.96$; Fig. $2 A, B)$.

We identified 118 putative interacting proteins from the abundance estimates provided by proteomic analysis of mAb295 immunopurified $\beta 2 *-n A C h R s$ from human temporal cortex. We excluded obvious contaminants (epidermal keratins, hornerin, hemoglobins, histones, cytochromes) and any protein with fewer than two unique peptides identified at a false discovery rate of $5 \%$. With these criteria applied, we identified and quantified 78 proteins that coimmunoprecipitated with $\beta 2 *-n A C h R s$ from human postmortem temporal cortex (Table 1). Of these, 42 proteins were identified as nAChR-interacting proteins in mouse cortex, and an additional 14 were isoforms of identified mouse cortex interacting proteins. An overlapping set of 36 proteins were identified in whole mouse brain as nAChR-interacting proteins, with an additional 17 isoforms of previously identified interacting proteins (McClure-Begley et al., 2013). Further, 33 of 78 proteins identified showed statistically significant correla- 

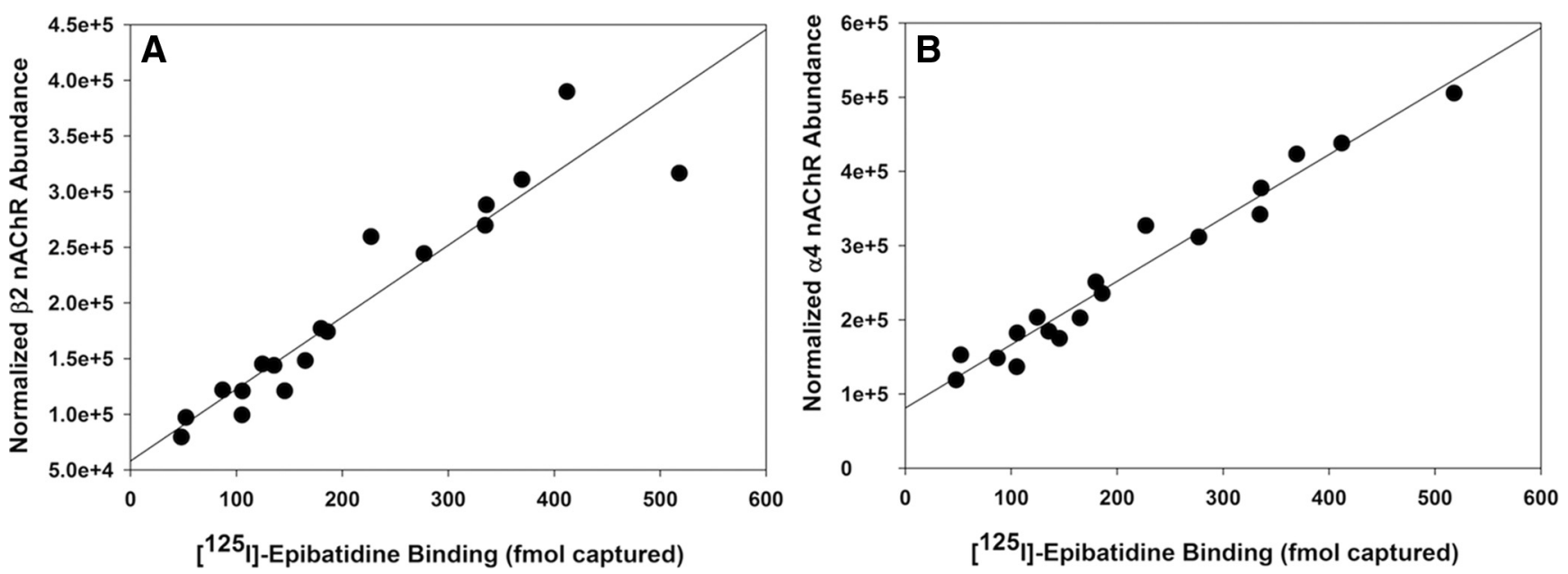

Figure 2. [125l]-epibatidine binding to $\alpha 4 \beta 2 *$-nAChRs in human temporal cortex homogenates correlates well with $\beta 2$-nAChR (A) and $\alpha 4$-nAChR (B) subunit abundance estimated by normalized unique peptide abundance determined by peptide LC-MS/MS.

tions of protein abundance with $\beta 2$-nAChR subunit abundance (Table 2), indicating a likely specific protein-protein interaction or physical proximity at the time of receptor extraction (Table 3). Functional annotation clustering of these 33 proteins using the DAVID Bioinformatics Database analysis (Huang da et al., 2009) showed a significant enrichment for synaptic pathways and neuronal projection (enrichment score, 5.47). Therefore, stable receptor interactions that survive tissue solubilization are likely assembled $\beta 2 *-n A C h R s$, and a subset of these nAChRs may be resident in the plasma membrane of neuronal synapses. The identification of a 14-3-3 isoform previously shown to mediate $\alpha 3 * n A C h R$ trafficking to postsynaptic structures (Rosenberg et al., 2008) indicates that some $\beta 2 *$ interactions are mediated on both sides of CNS synapses by this family of adaptor proteins. Based on the current dataset, it is possible that some of the captured $\beta 2 *-n A C h R s$ reside in the postsynaptic plasma membrane, but we failed to identify additional known postsynaptic density components or associated proteins with functional annotations placing them in that neuronal subcellular compartment, so additional experiments will be required to address variations in postsynaptic versus presynaptic $\beta 2 *-n A C h R$-interacting proteins.

\section{Immunoprecipitation of $\beta 2 *-n A C h R s$ from mouse cortex and identification of specific interacting proteins by tandem mass spectrometry}

As for the human samples, $\beta 2 \mathrm{nAChR}$ binding sites in mouse cortex samples were immunoprecipitated by mAb295-Dynabeads and subsequently quantitated by $\left[1^{125}\right]$-epibatidine binding. Binding site capture normalized to total tissue weight demonstrated significant effects of nicotine treatment and genotype (Fig. 3), but not a significant interaction (two-way ANOVA; main effect, nicotine, $F_{(1,15)}=29.05, p<0.0009$; main effect, genotype: $F_{(3,15)}=59.314, p<0.0009$; interaction, $F_{(3,15)}=$ 3.846, $p=0.057$ ).

Proteins identified and quantified from mouse cortex were analyzed, as has been described by McClure-Begley et al. (2013), using identical criteria for inclusion and exclusion as the human tissue samples. Each mouse sample was pooled from three mice (two pools per condition $\times$ eight conditions [nicotine-treated and untreated mice; wild-type, heterozygous, double-heterozygous, and knock-out mice]), and we mixed the mouse tissue such that each sample contained a total of $\sim 0.62 \mathrm{~g}$ wet weight. As expected, nAChR abundance calculated from the depletion of specific [ $\left.{ }^{125} \mathrm{I}\right]$-epibatidine binding sites (as femtomoles/milligram protein) correlated very well with the iTRAQ abundance ratios of $\alpha 4-$ and $\beta 2-\mathrm{nAChR}$ subunits $\left(r^{2}=0.77\right.$ and 0.70 , respectively).

Identified proteins were considered to be significant interactors according to the overall correlation of the log2transformed ratios of mean iTRAQ reporter ions with the control sample for each set (in these samples, the control is tissue from wild-type animals; Fig. 3, WT treated with saline). We observed a total of 184 coimmunopurified proteins from the mouse cortex samples, and, after the elimination of obvious contaminants and proteins identified in only one biological replicate, there were 94 proteins in common between the human and mouse experiments (Table 4). Of the 94 proteins identified in both biological replicates (Table 4), 5 were significantly correlated with $\beta 2-n A C h R$ subunit abundance; statistical power was reduced compared with the human samples because individuals in the mouse study were pooled for measurement rather than used as biological replicates (Table 5). In addition, the comparative mouse nAChR-associated proteomes were collected using a peptide-labeling iTRAQ strategy, which has been shown previously to provide less comprehensive sequence coverage and fewer quantitative differences than LFQ (Latosinska et al., 2015). Of the 94 proteins identified in the nAChR interactome in mouse cortex, only 19 were not identified in the human cortex samples directly, or as a close isoform (Table 4). Further comparison to proteins associated with the $\beta 2-n A C h R$ subunit in whole mouse brain (McClure-Begley et al., 2013) identified 37 proteins that were also immunoprecipitated from mouse and human cortex (Table 6). Com- 
Table 1. Tabulation of all proteins identified from mAb295-immunoisolated $\beta 2 *-n A C h R s$ from human temporal cortex, indicating which proteins have been identified in mouse cortex or whole mouse brain (Iso, isoform of protein identified; GN, gene name)

\begin{tabular}{|c|c|c|c|}
\hline Accession_HUMAN & Description & Mouse Ctx & Mouse Brain \\
\hline 1433E & 14-3-3 protein $\varepsilon$ GN $=$ YWHAE & Iso & Iso \\
\hline 1433G;1433F & 14-3-3 protein $\gamma \mathrm{GN}=$ YWHAG & Iso & Iso \\
\hline $1433 S$ & 14-3-3 protein $\sigma \mathrm{GN}=\mathrm{SFN}$ & Iso & Iso \\
\hline $1433 Z$ & 14-3-3 protein $\zeta / \delta \mathrm{GN}=\mathrm{YWHAZ}$ & Iso & Yes \\
\hline ACHA4;ACHA2;ACHA6 & Neuronal acetylcholine receptor subunit $\alpha 4 \mathrm{GN}=\mathrm{CHRNA} 4$ & Yes & Yes \\
\hline ACHB2 & Neuronal acetylcholine receptor subunit $\beta 2 \mathrm{GN}=\mathrm{CHRNB2}$ & Yes & Yes \\
\hline ACTB;ACTBM;РОTEE & Actin, cytoplasmic $1 \mathrm{GN}=\mathrm{ACTB}$ & Yes & Iso \\
\hline ACTC;ACTA & Actin, $\alpha$ cardiac muscle $1 \mathrm{GN}=$ ACTC 1 & Iso & Yes \\
\hline ACTN1;ACTN3 & $\alpha$-Actinin-1 GN $=$ ACTN1 & No & Yes \\
\hline ACTN2 & $\alpha$-Actinin-2 GN $=$ ACTN2 & No & Yes \\
\hline ACTN4 & $\alpha$-Actinin-4 GN $=$ ACTN4 & No & Iso \\
\hline ADDA & $\alpha$-Adducin GN = ADD1 & No & No \\
\hline ADT1;ADT2;ADT4 & ADP/ATP translocase $1 \mathrm{GN}=$ SLC25A4 & Yes & Yes \\
\hline ALBU & Serum albumin $\mathrm{GN}=\mathrm{ALB}$ & No & No \\
\hline ANK2 & Ankyrin-2 GN = ANK2 & No & Yes \\
\hline AP1B1 & AP-1 complex subunit $\beta 1 \mathrm{GN}=\mathrm{AP} 1 \mathrm{~B} 1$ & No & No \\
\hline ARP2 & Actin-related protein $2 \mathrm{GN}=$ ACTR2 & No & Iso \\
\hline ARP3 & Actin-related protein $3 \mathrm{GN}=\mathrm{ACTR} 3$ & No & Yes \\
\hline ARPC3 & Actin-related protein $2 / 3$ complex subunit $3 \mathrm{GN}=$ ARPC3 & No & Iso \\
\hline ARPC4 & Actin-related protein $2 / 3$ complex subunit $4 \mathrm{GN}=$ ARPC 4 & No & Iso \\
\hline AT1A1;AT12A & Sodium/potassium-transporting ATPase subunit $\alpha 1 \mathrm{GN}=$ ATP1A1 & Iso & Iso \\
\hline AT1A2 & Sodium/potassium-transporting ATPase subunit $\alpha 2$ GN = ATP1A2 & Iso & Yes \\
\hline AT1A3;AT1A4;ATP4A & Sodium/potassium-transporting ATPase subunit $\alpha 3 \mathrm{GN}=$ ATP1A3 & Yes & Yes \\
\hline AT1B1 & Sodium/potassium-transporting ATPase subunit $\beta 1 \mathrm{GN}=$ ATP1B1 & Yes & Yes \\
\hline AT2B2;AT2B1 & Plasma membrane calcium-transporting ATPase $2 \mathrm{GN}=$ ATP2B2 & No & No \\
\hline ATPA & ATP synthase subunit $\alpha$, mito GN $=$ ATP5A1 & Yes & Yes \\
\hline ATPB & ATP synthase subunit $\beta$, mito $\mathrm{GN}=$ ATP5B & Yes & Yes \\
\hline BASP1 & Brain acid-soluble protein $1 \mathrm{GN}=$ BASP1 & No & No \\
\hline CALM & Calmodulin GN = CALM1 & Yes & Yes \\
\hline CANB1 & Calcineurin subunit B type $1 \mathrm{GN}=$ PPP3R1 & No & No \\
\hline CLH1 & Clathrin heavy chain $1 \mathrm{GN}=\mathrm{CLTC} \mathrm{SV}=5$ & Yes & No \\
\hline CNTN1 & Contactin-1 GN = CNTN1 & No & Yes \\
\hline COX2 & Cytochrome c oxidase subunit $2 \mathrm{GN}=\mathrm{MT}-\mathrm{CO} 2$ & No & Yes \\
\hline COX41 & Cytochrome c oxidase subunit 4 isoform 1 , mito $\mathrm{GN}=\mathrm{COX} 4 \mathrm{I} 1$ & No & Yes \\
\hline COX6C & Cytochrome c oxidase subunit $6 \mathrm{C}$ GN $=\mathrm{COX} 6 \mathrm{C}$ & No & Yes \\
\hline CX6B1 & Cytochrome c oxidase subunit 6B1 GN = COX6B1 & No & Yes \\
\hline CX7A2 & Cytochrome $\mathrm{c}$ oxidase subunit $7 \mathrm{~A} 2$, mito $\mathrm{GN}=\mathrm{COX} 7 \mathrm{~A} 2$ & No & Yes \\
\hline DREB & Drebrin $\mathrm{GN}=\mathrm{DBN} 1$ & No & Yes \\
\hline DYN1 & Dynamin-1 GN = DNM1 & No & No \\
\hline E41L3 & Band 4.1-like protein $3 \mathrm{GN}=\mathrm{EPB} 41 \mathrm{L3}$ & No & No \\
\hline EAA1 & Excitatory amino acid transporter $1 \mathrm{GN}=\mathrm{SLC} 1 \mathrm{~A} 3$ & Iso & Iso \\
\hline EAA2 & Excitatory amino acid transporter $2 \mathrm{GN}=\mathrm{SLC} 1 \mathrm{~A} 2$ & Yes & Yes \\
\hline EF1A1;EF1A2 & Elongation factor $1-\alpha 1 \mathrm{GN}=\mathrm{EEF} 1 \mathrm{~A} 1$ & No & No \\
\hline FCGBP & IgGFc-binding protein GN = FCGBP & No & No \\
\hline $\mathrm{FRIH}$ & Ferritin heavy chain $\mathrm{GN}=\mathrm{FTH} 1$ & No & No \\
\hline FRIL & Ferritin light chain $\mathrm{GN}=\mathrm{FTL}$ & No & No \\
\hline G3P & Glyceraldehyde-3-phosphate dehydrogenase GN = GAPDH & Yes & Yes \\
\hline GBB1;GBB2;GBB3;GBB4 & Guanine nucleotide-binding protein $\mathrm{G}(\mathrm{I}) / \mathrm{G}(\mathrm{S}) / \mathrm{G}(\mathrm{T})$ subunit $\beta 1 \mathrm{GN}=\mathrm{GNB} 1$ & Yes & Yes \\
\hline GELS & Gelsolin GN = GSN & No & Yes \\
\hline GFAP & Glial fibrillary acidic protein $\mathrm{GN}=\mathrm{GFAP}$ & Yes & Yes \\
\hline GNAO;GNA12 & Guanine nucleotide-binding protein $\mathrm{G}(0)$ subunit $\alpha \mathrm{GN}=\mathrm{GNAO1}$ & Yes & Yes \\
\hline GPM6A & Neuronal membrane glycoprotein M6-a GN = GPM6A & No & No \\
\hline $\mathrm{H} 13$ & Histone H1.3 GN = HIST1H1D & No & Iso \\
\hline H2A1B & Histone $\mathrm{H} 2 \mathrm{~A}$ type $1-\mathrm{B} / \mathrm{E} \mathrm{GN}=\mathrm{HIST} 1 \mathrm{H} 2 \mathrm{AB}$ & No & Yes \\
\hline H2B1M;H2B1A & Histone H2B type 1-M GN = HIST1H2BM & No & Yes \\
\hline $\mathrm{H} 4$ & Histone H4 GN = HIST1H4A & No & Yes \\
\hline HBA & Hemoglobin subunit $\alpha \mathrm{GN}=\mathrm{HBA} 1$ & No & Iso \\
\hline HBB;HBD & Hemoglobin subunit $\beta \mathrm{GN}=\mathrm{HBB}$ & No & Yes \\
\hline HORN & Hornerin GN = HRNR & No & No \\
\hline HS12A & Heat shock $70 \mathrm{kDa}$ protein $12 \mathrm{~A}$ GN $=$ HSPA12A & No & Iso \\
\hline HS71L & $\begin{array}{c}\text { Heat shock } 70 \mathrm{kDa} \text { protein 1-like GN }=\text { HSPA1L } \\
\text { (Continued) }\end{array}$ & No & Iso \\
\hline
\end{tabular}


Table 1. Continued

\begin{tabular}{|c|c|c|c|}
\hline Accession_HUMAN & Description & Mouse Ctx & Mouse Brain \\
\hline HSPB1 & Heat shock protein $\beta 1 \mathrm{GN}=\mathrm{HSPB} 1$ & No & Iso \\
\hline IGHG4;IGHG2 & $\lg \gamma-4$ chain $\mathrm{C}$ region $\mathrm{GN}=\mathrm{IGHG} 4$ & No & Iso \\
\hline IGHM & Ig $\mu$ chain $\mathrm{C}$ region $\mathrm{GN}=\mathrm{IGHM}$ & No & Yes \\
\hline IGKC & $\lg \kappa$ chain $\mathrm{C}$ region $\mathrm{GN}=\mathrm{IGKC}$ & No & Iso \\
\hline KCC2A;KCC2D & Calcium/calmodulin-dependent protein kinase type II subunit $\alpha \mathrm{GN}=\mathrm{CAMK} 2 \mathrm{~A}$ & Yes & Yes \\
\hline KCC2B;KCC2G & Calcium/calmodulin-dependent protein kinase type II subunit $\beta$ GN $=$ CAMKIIB & Yes & Yes \\
\hline MBP & Myelin basic protein GN = MBP & Yes & Yes \\
\hline ML12A;MYL9 & Myosin regulatory light chain $12 \mathrm{~A}$ GN $=\mathrm{MYL12A}$ & No & Iso \\
\hline MOG & Myelin-oligodendrocyte glycoprotein $\mathrm{GN}=\mathrm{MOG}$ & No & No \\
\hline MPCP & Phosphate carrier protein, mito $\mathrm{GN}=\mathrm{SLC} 25 \mathrm{~A} 3$ & Yes & Yes \\
\hline MYH10 & Myosin-10 GN = MYH10 & Yes & Yes \\
\hline MYH9;MYH11;MYH14 & Myosin-9 GN = MYH9 & Iso & Yes \\
\hline MYL6;MYL6B & Myosin light polypeptide $6 \mathrm{GN}=$ MYL6 & Yes & Yes \\
\hline MYO5A;MY05B & Unconventional myosin-Va GN = MYO5A & No & Yes \\
\hline MYPR & Myelin proteolipid protein GN = PLP1 & No & Yes \\
\hline NDUA4 & Cytochrome $\mathrm{c}$ oxidase subunit NDUFA4 GN = NDUFA4 & Yes & Iso \\
\hline NDUS3 & NADH dehydrogenase [ubiquinone] iron-sulfur protein 3 , mito GN = NDUFS3 & Yes & Yes \\
\hline NDUV2 & NADH dehydrogenase [ubiquinone] flavoprotein 2 , mito GN = NDUFV2 & Yes & Yes \\
\hline NFL & Neurofilament light polypeptide GN = NEFL & Yes & Yes \\
\hline NFM & Neurofilament medium polypeptide GN = NEFM & Yes & Yes \\
\hline NSF & Vesicle-fusing ATPase GN = NSF & No & Yes \\
\hline ODB2 & $\begin{array}{l}\text { Lipoamide acyltransferase of branched-chain } \alpha \text {-keto acid dehydrogenase } \\
\text { mito GN = DBT }\end{array}$ & No & Yes \\
\hline ODO2 & $\begin{array}{l}\text { Dihydrolipoyllysine-residue succinyltransferase 2-oxoglutarate dehydrogenase } \\
\text { mito GN = DLST }\end{array}$ & Yes & Yes \\
\hline QCR2 & Cytochrome b-c1 complex subunit 2, mito GN = UQCRC2 & No & Yes \\
\hline RAB1A & Ras-related protein Rab-1A GN = RAB1A & Iso & Yes \\
\hline RL40 & Ubiquitin-60S ribosomal protein L40 GN = UBA52 & No & No \\
\hline R052 & E3 ubiquitin-protein ligase TRIM21 GN = TRIM21 & No & No \\
\hline S10A7;S1A7A & Protein S100-A7 GN = S100A7 & No & No \\
\hline S10A8 & Protein S100-A8 GN = S100A8 & No & No \\
\hline S10A9 & Protein S100-A9 GN = S100A9 & No & No \\
\hline SIR2 & NAD-dependent protein deacetylase sirtuin-2 GN = SIRT2 & No & No \\
\hline SNP25 & Synaptosomal-associated protein 25 GN = SNAP25 & Yes & Yes \\
\hline SPTB2;SPTB1 & Spectrin $\beta$ chain, nonerythrocytic $1 \mathrm{GN}=$ SPTBN1 & Yes & Yes \\
\hline SPTN1 & Spectrin $\alpha$ chain, nonerythrocytic $1 \mathrm{GN}=$ SPTAN 1 & Yes & Yes \\
\hline SPTN2 & Spectrin $\beta$ chain, nonerythrocytic $2 \mathrm{GN}=\mathrm{SPTBN} 2$ & Iso & Iso \\
\hline SSBP & Single-stranded DNA-binding protein, mito GN = SSBP1 & No & No \\
\hline STX1A & Syntaxin-1A GN = STX1A & Iso & Iso \\
\hline STX1B;STX2 & Syntaxin-1B GN = STX1B & Yes & Yes \\
\hline STXB1 & Syntaxin-binding protein $1 \mathrm{GN}=\mathrm{STXBP} 1$ & No & Yes \\
\hline SV2A & Synaptic vesicle glycoprotein $2 \mathrm{~A}$ GN $=$ SV2A & No & No \\
\hline SYT1 & Synaptotagmin-1 GN = SYT1 & Yes & Yes \\
\hline TBA1A,C;TBA3C,E;TBA8 & Tubulin $\alpha 1 \mathrm{~A}$ chain $\mathrm{GN}=\mathrm{TUBA} 1 \mathrm{~A}$ & Iso & Yes \\
\hline TBA1B & Tubulin $\alpha 1 \mathrm{~B}$ chain $\mathrm{GN}=\mathrm{TUBA} 1 \mathrm{~B}$ & Iso & Iso \\
\hline TBA4A;TBA4B;TBAL3 & Tubulin $\alpha 4 \mathrm{~A}$ chain $\mathrm{GN}=\mathrm{TUBA} 4 \mathrm{~A}$ & Yes & Yes \\
\hline TBB2A;TBB1;TBB2B & Tubulin $\beta 2 \mathrm{~A}$ chain $\mathrm{GN}=$ TUBB2A & Yes & Yes \\
\hline TBB3 & Tubulin $\beta 3$ chain $\mathrm{GN}=$ TUBB3 & Yes & Yes \\
\hline TBB4A;TBB6,8;TBB8L & Tubulin $\beta 4 \mathrm{~A}$ chain $\mathrm{GN}=$ TUBB4A & Yes & Yes \\
\hline TBB4B & Tubulin $\beta 4 \mathrm{~B}$ chain $\mathrm{GN}=$ TUBB4B & Yes & Yes \\
\hline TBB5 & Tubulin $\beta$ chain $\mathrm{GN}=$ TUBB & Yes & Yes \\
\hline THY1 & Thy-1 membrane glycoprotein $\mathrm{GN}=\mathrm{THY} 1$ & Yes & No \\
\hline TMOD2 & Tropomodulin-2 GN = TMOD2 & No & Yes \\
\hline TPM4;TPM1 & Tropomyosin $\alpha 4$ chain GN = TPM4 & Iso & No \\
\hline VAOD1;VA0D2 & V-type proton ATPase subunit d 1 GN = ATP6V0D1 & Yes & Iso \\
\hline VAMP3 & Vesicle-associated membrane protein $3 \mathrm{GN}=$ VAMP3 & No & Iso \\
\hline VATA & V-type proton ATPase catalytic subunit A GN = ATP6V1A & Yes & Yes \\
\hline VISL1 & Visinin-like protein $1 \mathrm{GN}=$ VSNL1 & No & No \\
\hline VPP1 & V-type proton ATPase $116 \mathrm{kDa}$ subunit a isoform $1 \mathrm{GN}=$ ATP6V0A1 PE = 2 & Yes & Iso \\
\hline
\end{tabular}

paring these proteins to those present in a common repository of contaminant proteins (Mellacheruvu et al., 2013), 11 proteins were identified $<10$ times in control studies, 7 were identified in $<100$ studies, 16 were identified in $>100$ control samples, and 3 were not present in the database (Table 6). 
Table 3. Proteins coimmunopurified with $\beta 2 *-n A C h R s$ from postmortem human temporal cortex with abundances that correlate significantly with the abundance of the $\beta 2 \mathrm{nAChR}$ subunit

\begin{tabular}{|c|c|c|c|c|}
\hline Accession & Description & Correlation $(r)$ & $p$ Value & $n$ \\
\hline ACHB2_HUMAN & Neuronal acetylcholine receptor subunit $\beta 2$ & 1 & 0 & 18 \\
\hline AT1B1_HUMAN & Sodium/potassium-transporting ATPase subunit $\beta 1$ & 0.889 & $<0.0009$ & 18 \\
\hline SNP25_HUMAN & Synaptosomal-associated protein 25 & 0.88 & $<0.0009$ & 18 \\
\hline STX1B_HUMAN & Syntaxin-1B & 0.874 & $<0.0009$ & 18 \\
\hline AT1A1_HUMAN & Sodium/potassium-transporting ATPase subunit $\alpha 1$ & 0.871 & $<0.0009$ & 18 \\
\hline GPM6Ā_HUMAN & Neuronal membrane glycoprotein M6-a & 0.823 & $<0.0009$ & 18 \\
\hline AT2B2_HUMAN & Plasma membrane calcium-transporting ATPase 2 & 0.781 & $<0.0009$ & 18 \\
\hline GNAO_HUMAN & Guanine nucleotide-binding protein $\mathrm{G}(\mathrm{o})$ subunit $\alpha$ & 0.781 & $<0.0009$ & 18 \\
\hline VPP1_HUMAN & V-type proton ATPase $116 \mathrm{kDa}$ subunit a isoform 1 & 0.777 & $<0.0009$ & 18 \\
\hline MYPR_HUMAN & Myelin proteolipid protein & 0.762 & $<0.0009$ & 18 \\
\hline GBB1_HUMAN & Guanine nucleotide-binding protein $\mathrm{G}(\mathrm{I}) / \mathrm{G}(\mathrm{S}) / \mathrm{G}(\mathrm{T})$ subunit $\beta 1$ & 0.702 & 0.001 & 18 \\
\hline TBB5_HUMAN & Tubulin $\beta$ chain & 0.576 & 0.012 & 18 \\
\hline TBA1A_HUMAN & Tubulin $\alpha 1 \mathrm{~A}$ chain & 0.56 & 0.016 & 18 \\
\hline 1433Z_HUMAN & 14-3-3 protein zeta/delta & 0.548 & 0.019 & 18 \\
\hline STXB1_HUMAN & Syntaxin-binding protein 1 & 0.526 & 0.025 & 18 \\
\hline SYT1_HUMAN & Synaptotagmin-1 & 0.523 & 0.026 & 18 \\
\hline CLH1_HUMAN & Clathrin heavy chain 1 & 0.515 & 0.041 & 18 \\
\hline TBA4A_HUMAN & Tubulin $\alpha 4 \mathrm{~A}$ chain & 0.514 & 0.029 & 18 \\
\hline S10A7_HUMAN & Protein S100-A7 & 0.511 & 0.03 & 18 \\
\hline TBA1B_HUMAN & Tubulin $\alpha 1 \mathrm{~B}$ chain & 0.506 & 0.032 & 18 \\
\hline RO52_HUMAN & E3 ubiquitin-protein ligase TRIM21 & 0.492 & 0.038 & 18 \\
\hline ODO2_HUMAN & $\begin{array}{l}\text { Dihydrolipoyllysine-residue succinyltransferase component } \\
\text { of 2-oxoglutarate dehydrogenase complex }\end{array}$ & 0.483 & 0.042 & 18 \\
\hline TBB4A_HUMAN & Tubulin $\beta 4 \mathrm{~A}$ chain & 0.476 & 0.046 & 18 \\
\hline
\end{tabular}

High correlation indicates the identified protein is either specifically interacting with the receptor at the time of tissue lysis or is part of a complex that stays intact following extraction in Triton X-100. The cluster of proteins with correlation coefficients $<0.7$ is evidence of significant enrichment of presynaptic components critical for neurotransmitter release and neuronal excitability.

\section{Effects of nicotine exposure and mood disorder on nAChR-associated proteins isolated from human temporal cortex}

To identify changes in the $\beta 2 *-n A C h R$-associated proteome due to nicotine exposure status or mood disorder, we compared the abundance ratios for every protein identified in each sample and performed GLM analysis to identify significant changes. Of the 33 putative interacting proteins identified following immunoprecipitation of $\beta 2 *-$ nAChRs from human cortex (Table 3), 14 proteins differed in interaction as a result of tobacco use, as measured by a shift in the ratio of the interacting protein to nAChR number between nonexposed and tobacco-exposed individuals, with two additional protein (14-3-3 $\zeta$ and ATP1A2) that showed a significant nicotine $\times$ mood disorder interaction (Fig. 4A, Table 7). None of the interactions were significantly altered by mood disorder alone (Table 7 ). Several of the changes in associated protein abundance appear to be affected more significantly by the combination of nicotine use and mood disorder (Fig. 4, open triangles) despite the nonsignificant interaction term calculated from the dataset as a whole. Normalizing protein abundance to $\beta 2 \mathrm{nAChR}$ content within each sample identified an independent set of five proteins that were significantly altered by nicotine use (Fig. $4 B$, Table 8); again, we did not identify significant differences by mood disorder diagnosis.

\section{Effects of nicotine exposure on nAChR-associated proteins isolated from mouse cortex}

In the mouse ITRAQ data, GLM analysis did not identify a significant effect of nicotine on any of the nAChRassociated proteins with expression indices significantly correlated with $\beta 2-\mathrm{nAChR}$ abundance. Although nicotine exposure did increase the abundance of the $\alpha 4$ - and $\beta 2$-nAChR subunits, the increase was only marginally significant (Chrna4: $F_{(1,13)}=4.93, p=0.06$; Chrnb2: $F_{(1,13)}$ $=4.67, p=0.07$ ), likely due to the small number of pools included in the analysis. In addition, the overall $n$ size of the experiment was reduced because the $\beta 2$-nAChR subunit abundance from the control groups is used as the denominator in their ratiometric quantitation, and is not included as a correlate to avoid bias due to artificially small errors on the calculated intercept. This ratiometric 


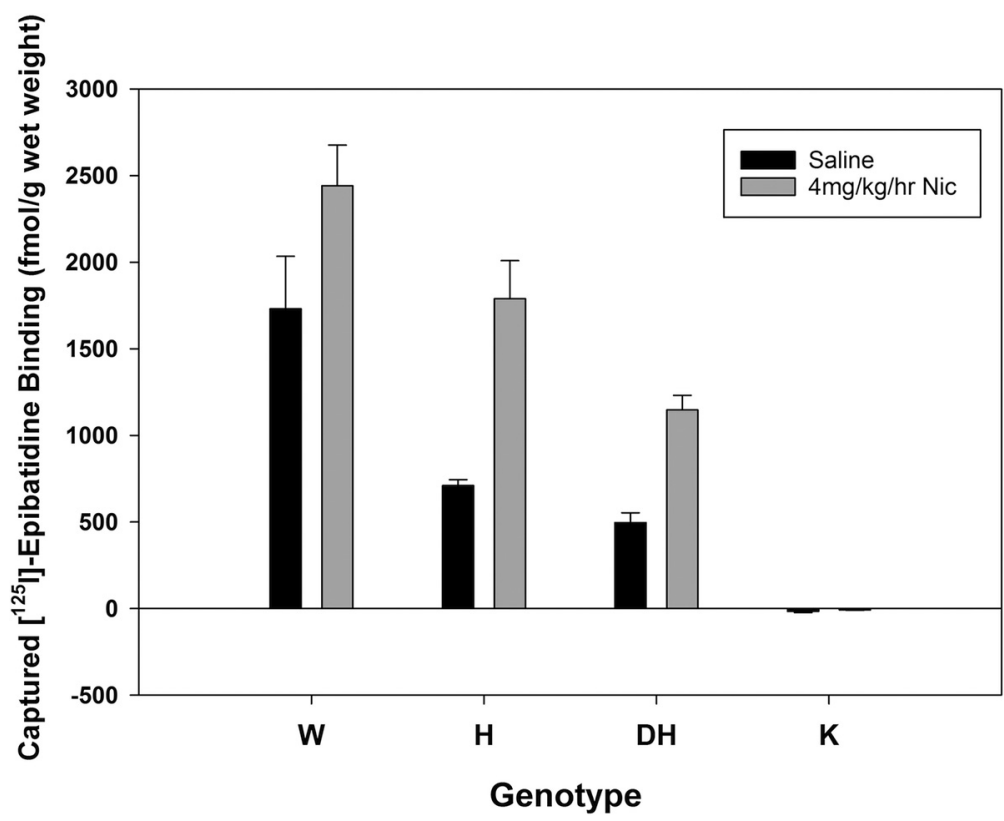

Figure 3. Effects of long-term treatment with saline or $4 \mathrm{mg} / \mathrm{kg} / \mathrm{h}$ nicotine treatment on captured [ $\left.{ }^{125} \mathrm{l}\right]$-epibatidine binding sites from pooled cortex from wild-type $\left(\beta 2^{+/+}, \mathrm{W}\right)$, heterozygous $\left(\beta 2^{+/-}, \mathrm{H}\right)$, double-heterozygous $\left(\alpha 4^{+/-} \beta 2^{+/-}, \mathrm{DH}\right)$, and knock-out $\left(\beta 2^{-/-}, \mathrm{K}\right)$ mice. Gene dose-dependent changes in receptor capture are apparent (two-way ANOVA; main effect, genotype: $F_{(3,15)}=59.314, p$ $<0.0009$ ), as is the upregulation produced by long-term nicotine exposure in all but the $\beta 2^{-1-}$ genotype groups (main effect, nicotine: $\left.F_{(1,15)}=29.05, p<0.0009\right)$. Error bars represent standard error of the mean.

quantitation also prevents normalization to $\beta 2-n A C h R$ subunit abundance within each sample, so a depiction of change relative to "per unit" $\beta 2$ is not possible. Analysis of genotype effects on iTRAQ-labeled nAChR peptides with GLM showed significance for all three subunits identified, as follows: Chrna4: $F_{(3,13)}=16.43, p=0.001$; Chrna5: $F_{(3,13)}=8.87, p=0.009$; Chrnb2: $F_{(3,13)}=12.78, p=$ 0.003 .

\section{Discussion}

In this study, we examined the effects of tobacco use and mood disorder on the expression of $\alpha 4 \beta 2 *-n A C h R s$ and their associated proteins in postmortem human cortex. We also used experiments in mice to determine the effects of nicotine alone on the associated proteome. Repeated or prolonged nicotine exposure increases $\alpha 4 \beta 2 *-n A C h R$ number in heterologous expression systems, animal models, and human tissue (for review, see Melroy-Greif et al., 2016). In addition, the changes in $\alpha 4 \beta 2 *-n A C h R$ content after long-term exposure to nicotine are brain region and cell type specific, with cortical regions among those most reproducibly affected in both mouse and human (Marks et al., 1992, 2011; Nashmi et al., 2007). Further, a substantial body of evidence points to a cholinergic contribution to the etiology and expression of affective disorders (for review, see Mineur and Picciotto, 2010), and that $\beta 2 *-n A C h R$ occupancy by endogenous $\mathrm{ACh}$ is significantly increased by current or past episodes of major depressive or bipolar disorder (Saricicek et al., 2012; Hannestad et al., 2013). Studies in mouse models indicate that even acute dysregulation of cholinergic neurotransmission can elicit changes in affec- tive states, and that long-term manipulation of acetylcholine levels leads to behavioral responses that are commonly indicative of mood disorders, specifically depression- and anxiety-like behaviors (Mineur et al., 2013). Identifying the interactions of $\alpha 4 \beta 2 *-n A C h R s$ with other synaptic proteins and functional regulators could therefore identify the novel elements of neuronal plasticity underlying the acquisition of nicotine tolerance and dependence, as well as improve understanding of how cholinergic regulation of mood is accomplished in the CNS.

For this study we measured cotinine levels in the brain tissue lysate (containing all of the cytosolic and interstitial fluid components) to establish nicotine/tobacco use status for each sample. After organizing the samples according to nicotine use and mood disorder status, we observed that the levels of $\alpha 4 \beta 2 *-n A C h R s$ measured by radioligand binding with $\left[{ }^{125} \mathrm{I}\right]$-epibatidine were consistent with significant receptor upregulation due to nicotine use. The levels of $\alpha 4$ - and $\beta 2-n A C h R$ subunits measured by label-free quantitative proteomics were consistent with the changes observed with ligand binding. These results indicated that, when performed appropriately, quantitative immunopurification and proteomics is a valid method for evaluating changes in $\mathrm{nAChR}$ expression.

A different form of quantitative proteomics (iTRAQ) was used to assess changes in $\alpha 4 \beta 2 *-n A C h R s$ and associated proteins from transgenic mouse tissue. iTRAQ uses amine-reactive isobaric labels to facilitate the ratiometric quantitation of peptides from multiplexed samples in a complex mixture (Wiese et al., 2007). Multiplexed iTRAQ 
Table 4. Tabulation of all proteins identified in common between two biological replicates of eight-plex iTRAQ-labeled $\beta 2 *-n A C h R s$ immunoisolated with mAb295 from mouse cortex, indicating which proteins have been identified in human temporal cortex or whole mouse brain (Iso, isoform of protein identified; GN, gene name)

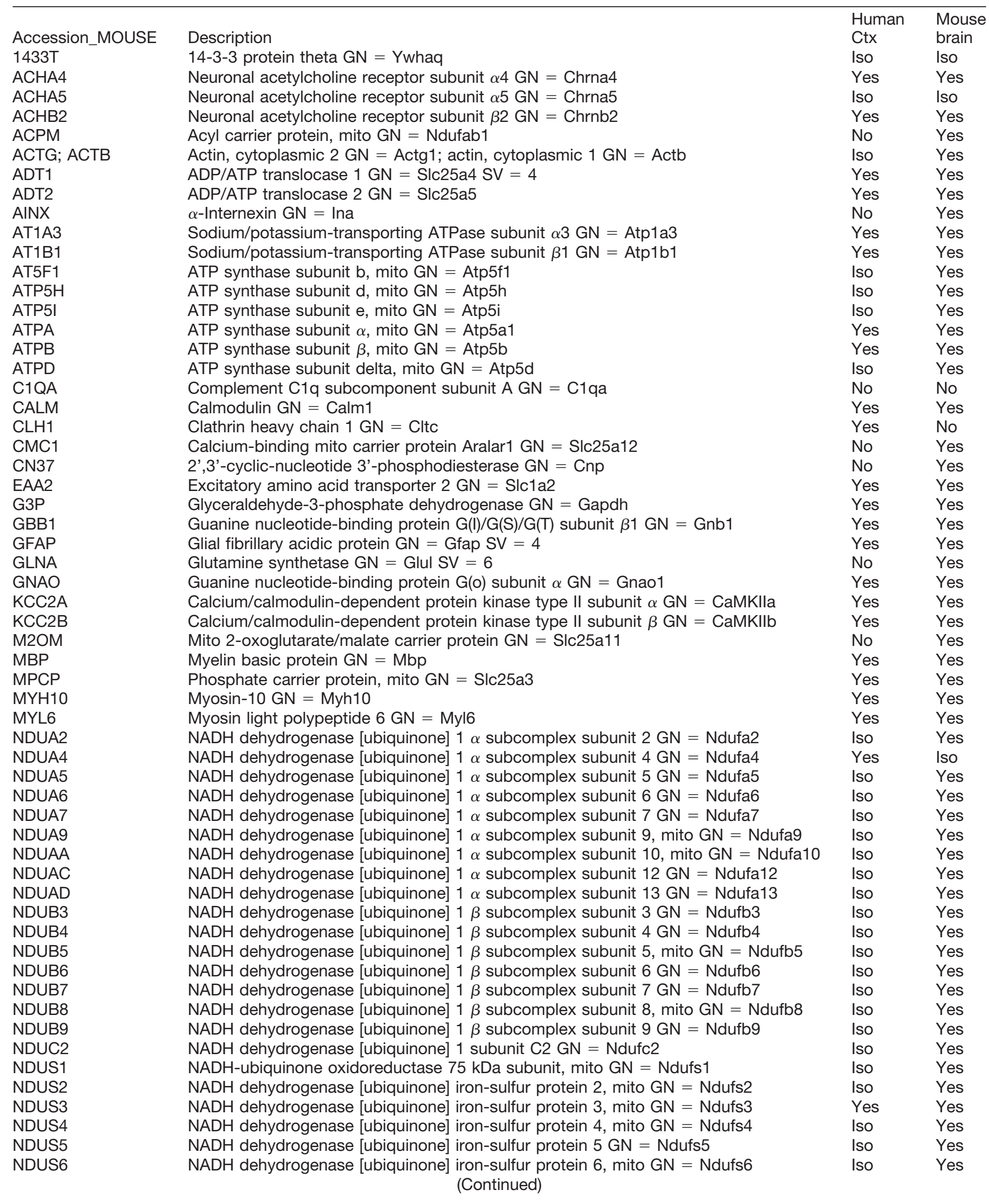


Table 4. Continued

\begin{tabular}{|c|c|c|c|}
\hline Accession_MOUSE & Description & $\begin{array}{l}\text { Human } \\
\text { Ctx }\end{array}$ & $\begin{array}{l}\text { Mouse } \\
\text { brain }\end{array}$ \\
\hline NDUS7 & NADH dehydrogenase [ubiquinone] iron-sulfur protein 7 , mito GN = Ndufs7 & Iso & Yes \\
\hline NDUS8 & NADH dehydrogenase [ubiquinone] iron-sulfur protein 8, mito $\mathrm{GN}=$ Ndufs8 & Iso & Yes \\
\hline NDUV1 & NADH dehydrogenase [ubiquinone] flavoprotein 1, mito GN = Ndufv1 & Iso & Yes \\
\hline NDUV2 & NADH dehydrogenase [ubiquinone] flavoprotein 2, mito GN = Ndufv2 & Yes & Yes \\
\hline NEST & Nestin $\mathrm{GN}=$ Nes & No & No \\
\hline $\mathrm{NFH}$ & Neurofilament heavy polypeptide GN = Nefh & Iso & Iso \\
\hline NFL & Neurofilament light polypeptide $\mathrm{GN}=\mathrm{Nefl} \mathrm{SV}=5$ & Yes & Yes \\
\hline NFM & Neurofilament medium polypeptide GN $=$ Nefm SV $=4$ & Yes & Yes \\
\hline OCAD2 & OCIA domain-containing protein $2 \mathrm{GN}=$ Ociad2 & No & Yes \\
\hline ODO2 & $\begin{array}{l}\text { Dihydrolipoyl-lysine residue succinyltransferas 2-oxoglutarate dehydrogenase complex, } \\
\text { mito GN = Dlst }\end{array}$ & Yes & Yes \\
\hline ODPA & Pyruvate dehydrogenase E1 component subunit $\alpha$, somatic form, mito $\mathrm{GN}=$ Pdha1 & No & Yes \\
\hline ODPB & Pyruvate dehydrogenase $\mathrm{E} 1$ component subunit $\beta$, mito $\mathrm{GN}=\mathrm{Pdhb}$ & No & Yes \\
\hline PHB & Prohibitin $\mathrm{GN}=\mathrm{Phb}$ & No & Yes \\
\hline $\mathrm{PHB2}$ & Prohibitin-2 GN = Phb2 & No & Yes \\
\hline RAB3A & Ras-related protein Rab-3A GN = Rab3a & Iso & Yes \\
\hline SFXN3 & Sideroflexin-3 GN = Sfxn3 & No & Yes \\
\hline SNP25 & Synaptosomal-associated protein 25 GN = Snap25 & Yes & Yes \\
\hline SPTB2 & Spectrin $\beta$ chain, nonerythrocytic $1 \mathrm{GN}=$ Sptbn1 & Yes & Yes \\
\hline SPTN1 & Spectrin $\alpha$ chain, nonerythrocytic $1 \mathrm{GN}=$ Sptan $1 \mathrm{SV}=4$ & Yes & Yes \\
\hline STX1B & Syntaxin-1B GN = Stx1b & Yes & Yes \\
\hline SYPH & Synaptophysin GN = Syp & No & No \\
\hline SYT1 & Synaptotagmin-1 GN = Syt1 & Yes & Yes \\
\hline TBA4A & Tubulin $\alpha 4 \mathrm{~A}$ chain $\mathrm{GN}=$ Tuba4a & Yes & Yes \\
\hline TBB2A & Tubulin $\beta 2 \mathrm{~A}$ chain $\mathrm{GN}=$ Tubb2a & Yes & Yes \\
\hline TBB3 & Tubulin $\beta 3$ chain $\mathrm{GN}=$ Tubb3 & Yes & Yes \\
\hline TBB4A & Tubulin $\beta 4 \mathrm{~A}$ chain $\mathrm{GN}=$ Tubb4a & Yes & Yes \\
\hline TBB4B & Tubulin $\beta 4 \mathrm{~B}$ chain $\mathrm{GN}=$ Tubb4b & Yes & Yes \\
\hline TBB5 & Tubulin $\beta 5$ chain $\mathrm{GN}=$ Tubb5 & Yes & Yes \\
\hline THY1 & Thy-1 membrane glycoprotein GN = Thy1 & Yes & No \\
\hline TPM3 & Tropomyosin $\alpha 3$ chain $\mathrm{GN}=$ Tpm3 & Iso & No \\
\hline VA0D1 & V-type proton ATPase subunit d $1 \mathrm{GN}=$ Atp6v0d1 & Yes & Iso \\
\hline VATA & V-type proton ATPase catalytic subunit A GN = Atp6v1a & Yes & Yes \\
\hline VDAC1 & Voltage-dependent anion-selective channel protein 1 GN = Vdac1 & No & Yes \\
\hline VDAC2 & Voltage-dependent anion-selective channel protein 2 GN = Vdac2 & No & Yes \\
\hline VIME & Vimentin $\mathrm{GN}=$ Vim & No & Yes \\
\hline VPP1 & V-type proton ATPase 116 kDa subunit a isoform $1 \mathrm{GN}=$ Atp6v0a1 & Yes & Iso \\
\hline
\end{tabular}

proteomics has been used previously with $\mathrm{nAChR}$ subunit transgenic mice to validate the approach for the untargeted identification of putative nAChR-associated proteins (McClure-Begley et al., 2013). In this project, we used iTRAQ to identify interacting proteins that are altered in their association with $\beta 2 *-n A C h R$ due to long-term nicotine treatment. It was our goal to test the hypothesis that a core set of $\alpha 4 \beta 2 *$ interacting partners would be conserved in the cortex from mouse to human, and that the identification of these complexes could guide future studies geared toward understanding $\mathrm{nAChR}$ regulation and function.

Table 5. $\beta 2 *-n A C h R$ interacting proteins identified by iTRAQ analysis of receptors isolated from transgenic mouse cortex receiving long-term treatment with nicotine and not receiving nicotine treatment (GN, gene name)

\begin{tabular}{|c|c|c|c|}
\hline Accession & Description & Correlation $(r)$ & $p$ Value \\
\hline splO70174IACHA4_MOUSE & $\begin{array}{l}\text { Neuronal acetylcholine receptor } \\
\text { subunit } \alpha 4 \mathrm{OS}=\text { Mus musculus } \mathrm{GN}=\text { Chrna4 PE }=2 \mathrm{SV}=2\end{array}$ & 0.97 & $<0.0009$ \\
\hline splQ2MKA5IACHA5_MOUSE & $\begin{array}{l}\text { Neuronal acetylcholine receptor subunit } \alpha 5 \mathrm{OS}=\text { Mus } \\
\text { musculus } \mathrm{GN}=\text { Chrna5 } \mathrm{PE}=2 \mathrm{SV}=1\end{array}$ & 0.91 & $<0.0009$ \\
\hline splQ9ERK7|ACHB2_MOUSE & $\begin{array}{l}\text { Neuronal acetylcholine receptor subunit } \beta 2 \mathrm{OS}=\text { Mus } \\
\text { musculus } \mathrm{GN}=\mathrm{Chrnb} 2 \mathrm{PE}=2 \mathrm{SV}=1\end{array}$ & 1 & $<0.0009$ \\
\hline sp|Q6PIC6IAT1A3_MOUSE & $\begin{array}{l}\text { Sodium/potassium-transporting ATPase subunit } \alpha 3 \mathrm{OS}=\text { Mus } \\
\text { musculus } \mathrm{GN}=\text { Atp1a3 } \mathrm{PE}=1 \mathrm{SV}=1\end{array}$ & 0.55 & 0.042 \\
\hline
\end{tabular}

Similar to the results from human cortex samples, presynaptic elements related to vesicle fusion (synaptophysin) and neuronal excitability (ATP1A3) are significantly correlated with nAChR levels. 
Table 6. List of proteins identified in three independent proteomic studies: human and mouse cortex (current study) and whole mouse brain (McClure-Begley et al., 2013) (GN, gene name)

\begin{tabular}{|c|c|c|}
\hline Accession & Description & $\begin{array}{l}\text { No. of experiment } \\
\text { (found/total) }\end{array}$ \\
\hline $\mathrm{ACHA} 4$ & Neuronal acetylcholine receptor subunit $\alpha 4 \mathrm{GN}=$ Chrna4 & $0 / 411$ \\
\hline $\mathrm{ACHB} 2$ & Neuronal acetylcholine receptor subunit $\beta 2 \mathrm{GN}=$ Chrnb2 & $0 / 411$ \\
\hline ADT1 & ADP/ATP translocase $1 \mathrm{GN}=\mathrm{Slc} 25 \mathrm{a} 4$ & $195 / 411$ \\
\hline ADT2 & ADP/ATP translocase $2 \mathrm{GN}=\mathrm{Slc} 25 \mathrm{a} 5$ & $223 / 411$ \\
\hline AT1A3 & Sodium/potassium-transporting ATPase subunit $\alpha 3 \mathrm{GN}=$ Atp1a3 & $101 / 411$ \\
\hline AT1B1 & Sodium/potassium-transporting ATPase subunit $\beta 1 \mathrm{GN}=$ Atp1b1 & $1 / 411$ \\
\hline ATPA & ATP synthase subunit $\alpha$, mito $\mathrm{GN}=$ Atp5a1 & $210 / 411$ \\
\hline ATPB & ATP synthase subunit $\beta$, mito $\mathrm{GN}=$ Atp $5 \mathrm{~b}$ & $211 / 411$ \\
\hline CALM & Calmodulin GN = Calm1 & $133 / 411$ \\
\hline EAA2 & Excitatory amino acid transporter $2 \mathrm{GN}=\mathrm{Slc} 1 \mathrm{a} 2$ & $2 / 411$ \\
\hline G3P & Glyceraldehyde-3-phosphate dehydrogenase GN = GAPDH & $248 / 411$ \\
\hline GBB1 & Guanine nucleotide-binding protein $\mathrm{G}(\mathrm{I}) / \mathrm{G}(\mathrm{S}) / \mathrm{G}(\mathrm{T})$ subunit $\beta 1 \mathrm{GN}=\mathrm{Gnb1}$ & $59 / 411$ \\
\hline GFAP & Glial fibrillary acidic protein GN = GFAP & $73 / 411$ \\
\hline GNAO & Guanine nucleotide-binding protein $\mathrm{G}(\mathrm{o})$ subunit $\alpha \mathrm{GN}=\mathrm{Gnao1}$ & $42 / 411$ \\
\hline KCC2A & Calcium/calmodulin-dependent protein kinase type II subunit $\alpha \mathrm{GN}=$ CaMKIla & $7 / 411$ \\
\hline KCC2B & Calcium/calmodulin-dependent protein kinase type II subunit $\beta \mathrm{GN}=\mathrm{CaMKIIb}$ & $7 / 411$ \\
\hline MBP & Myelin basic protein $\mathrm{GN}=\mathrm{Mbp}$ & $0 / 411$ \\
\hline MPCP & Phosphate carrier protein, mito $\mathrm{GN}=\mathrm{Slc} 25 \mathrm{a} 3$ & $130 / 411$ \\
\hline MYH10 & Myosin-10 GN = Myh10 & $166 / 411$ \\
\hline MYL6 & Myosin light polypeptide $6 \mathrm{GN}=$ Myl6 & $190 / 411$ \\
\hline NDUS3 & $\mathrm{NADH}$ dehydrogenase [ubiquinone] iron-sulfur protein 3, mito $\mathrm{GN}=$ Ndufs3 & $19 / 411$ \\
\hline NDUV2 & NADH dehydrogenase [ubiquinone] flavoprotein 2, mito GN = Ndufv2 & $3 / 411$ \\
\hline NFL & Neurofilament light polypeptide $\mathrm{GN}=$ Nefl & Not in database \\
\hline NFM & Neurofilament medium polypeptide GN $=$ Nefm & $85 / 411$ \\
\hline ODO2 & $\begin{array}{l}\text { Dihydrolipoyllysine-res succinyltransferase 2-oxoglutarate dehydrogenase complex, } \\
\text { mito GN = Dlst }\end{array}$ & $57 / 411$ \\
\hline SNP25 & Synaptosomal-associated protein $25 \mathrm{GN}=$ Snap25 & $0 / 411$ \\
\hline SPTB2 & Spectrin $\beta$ chain, nonerythrocytic $1 \mathrm{GN}=$ Sptbn 1 & $143 / 411$ \\
\hline SPTN1 & Spectrin $\alpha$ chain, nonerythrocytic $1 \mathrm{GN}=$ Sptan 1 & $161 / 411$ \\
\hline STX1B & Syntaxin-1B GN = Stx1b & $0 / 411$ \\
\hline SYT1 & Synaptotagmin-1 GN = Syt1 & $0 / 411$ \\
\hline TBA4A & Tubulin $\alpha 4 \mathrm{~A}$ chain $\mathrm{GN}=$ Tuba4a & $377 / 411$ \\
\hline TBB2A & Tubulin $\beta 2 \mathrm{~A}$ chain $\mathrm{GN}=$ Tubb2a & $372 / 411$ \\
\hline TBB3 & Tubulin $\beta 3$ chain $\mathrm{GN}=$ Tubb3 & Not in database \\
\hline TBB4A & Tubulin $\beta 4 \mathrm{~A}$ chain $\mathrm{GN}=$ Tubb4a & $366 / 411$ \\
\hline TBB4B & Tubulin $\beta 4 \mathrm{~B}$ chain $\mathrm{GN}=$ Tubb4b & $376 / 411$ \\
\hline TBB5 & Tubulin $\beta 5$ chain $\mathrm{GN}=$ Tubb5 & Not in database \\
\hline VATA & V-type proton ATPase catalytic subunit A GN $=$ Atp6v1a & $62 / 411$ \\
\hline
\end{tabular}

Numbers in the right hand column represent the number of times each protein has been identified in control studies designed to evaluate background contaminants (Mellacheruvu et al., 2013).

We took advantage of the inherent variability in $\beta 2 *-$ nAChR abundance across samples (due to either individual differences and/or nicotine use status in the case of the human samples, and genetic control of nAChR abundance and nicotine exposure in the mouse samples) to match linear relationships of protein abundance indices with the measured abundance of $\beta 2-n A C h R s$, providing confidence that the proteins coimmunopurifying with the $\beta 2 *-n A C h R s$ interact in a meaningful context. Abundance correlations would be expected to be random and nonsignificantly correlated if interactions were nonspecific. We observed a high level of overlap between human and mouse cortical samples of signaling complexes coimmunoprecipitated with $\beta 2 *-n A C h R s$.

The functional roles of $n A C h R s$ as neuromodulators on presynaptic terminals of many different neuronal types have been described in numerous previous studies (for review, see Barik and Wonnacott, 2009). Evidence in the current study from bottom-up quantitative proteomic analysis of $\alpha 4 \beta 2 *-n A C h R$-associated proteins identified in human and mouse cortical tissue not only supports a presynaptic role for these receptors, but assigns additional proteins with known roles in neurotransmitter release and neuronal excitability that begin to describe the composition of specific signaling complexes assembled with nAChRs. Specifically, components of the presynaptic active zone and the SNARE complex (syntaxin1B, syntaxin $1 \mathrm{~A}$, syntaxin binding protein-1, SNAP25, and synaptotagmin) were identified with significant expression correlations with $\beta 2$-nAChR subunits in the human temporal cortex samples; the same core set of proteins were also identified in the mouse cortex ITRAQ analysis. Smaller sample size due to the pooling of individual mice for analyses limited statistically significant correlation to synaptophysin; however, identification across two species with differing exposure modalities increases confi- 
Table 7. $\beta 2 *-n A C h R$-associated proteins with abundances that are significantly affected by nicotine use and/or mood disorder status in human temporal cortex

\begin{tabular}{lllll}
\hline Accession & Description & Significant effect & $F$ & $p$ Value \\
1433Z_HUMAN & 14-3-3 protein zeta/delta & MD x Nicotine & $F_{(1,17)}=4.943$ & 0.043 \\
ACHA4_HUMAN & Neuronal acetylcholine receptor subunit $\alpha 4$ & Nicotine & $F_{(1,17)}=16.596$ & $<0.0009$ \\
ACHB2_HUMAN & Neuronal acetylcholine receptor subunit $\beta 2$ & Nicotine & $F_{(1,17)}=12.881$ & $<0.0009$ \\
AT1A1_HUMAN & Sodium/potassium-transporting ATPase subunit $\alpha 1$ & Nicotine & $F_{(1,17)}=7.460$ & 0.016 \\
AT1A2_HUMAN & Sodium/potassium-transporting ATPase subunit $\alpha 2$ & Nicotine, MD $\times$ nicotine & $F_{(1,17)}=5.749 ;$ & $0.031 ; 0.047$ \\
& & & $F_{(1,17)}=4.740$ \\
AT1A3_HUMAN & Sodium/potassium-transporting ATPase subunit $\alpha 3$ Nicotine & Nine & $F_{(1,17)}=5.820$ & 0.03 \\
AT1B1_HUMAN & Sodium/potassium-transporting ATPase subunit $\beta 1$ & Nicotine & $F_{(1,17)}=7.537$ & 0.016 \\
AT2B2_HUMAN & Plasma membrane calcium-transporting ATPase 2 & Nicotine & $F_{(1,17)}=13.246$ & 0.003 \\
GNAO_HUMAN & Guanine nucleotide-binding protein G(0) subunit $\alpha$ & Nicotine & $F_{(1,17)}=5.077$ & 0.041 \\
MYPR_HUMAN & Myelin proteolipid protein & Nicotine & $F_{(1,17)}=8.779$ & 0.01 \\
S10A7_HUMAN & Protein S100-A7 & Nicotine & $F_{(1,17)}=5.850$ & 0.03 \\
SNP25_HUMAN & Synaptosomal-associated protein 25 & Nicotine & $F_{(1,17)}=11.990$ & 0.004 \\
STX1A_HUMAN & Syntaxin-1A & Nicotine & $F_{(1,17)}=11.506$ & 0.004 \\
STX1B_HUMAN & Syntaxin-1B & Nicotine & $F_{(1,17)}=11.792$ & 0.004 \\
VPP1_HUMAN & V-type proton ATPase 116 kDa subunit a isoform 1 Nicotine & $F_{(1,17)}=5.946$ & 0.029
\end{tabular}

Nicotine use has the largest statistical effect observed in terms of its impact on $\beta 2 *-n A C h R$ expression and the abundance of associated proteins. Only two proteins (14-3-3 $\zeta$ and ATP1A2) show a significant interaction between nicotine use and mood disorder.

dence that interaction of the set of nAChR-associated proteins identified from human brain are altered as a result of nicotine exposure.

Of the 17 proteins that were identified previously with ITRAQ using stringent criteria for dose relationships in mice with varying nAChR genotype in whole mouse brain (McClure-Begley et al., 2013), 8 were identified in both mouse and human cortex in the current study ( $\alpha 4-$ and $\beta 2$-nAChR subunits, CaMKII $\alpha$, spectrin $\alpha$ and $\beta$, myosin 10 , tubulin $\beta 3$, and GFAP; Tables 1, 2). Syntaxin 1B, synaptotagmin 1 , syntaxin binding protein 1 , and several 14-3-3 isoforms were also identified in all three datasets. These proteins, although clearly identified in the nAChRassociated proteome from whole mouse brain, did not meet the stringent criteria for variance with gene dose. One possibility is that each of these proteins is limiting in the compartment (synaptic or ER) in which it interacts with nAChRs, and that the interaction is functional and transient (during vesicle recruitment or release, or during nAChR assembly), so it does not scale with nAChR number. Of those proteins that were not identified in the current study, several proteins were represented by different isoforms or by other proteins with related functions. For example, while the current study did not identify CaMKII $\gamma$, the $\beta$-isoform was identified in both mouse and human cortical samples, perhaps because the $\gamma$-isoform is more highly expressed in other brain regions, and the $\beta$-isoform in enriched in cortex.

Many subtypes of $\mathrm{nAChRs}$ have been identified as presynaptic heteroreceptors that can directly influence neurotransmitter release, and the identification of SNARE complex proteins as significant nAChR interactors in both the mouse and human tissue samples suggests a functional interaction between $\alpha 4 \beta 2 *$-nAChRs and neurotransmitter release machinery. Minimally, this association indicates that some $\alpha 4 \beta 2 *$-nAChRs are extremely close to sites on presynaptic terminals where neurotransmitter release is actively taking place. Such close physical association suggests that nAChRs may exert some modulatory influence on neu- rotransmitter release independently of action potential arrival or frequency, and highlights their potential role as a "finetuning" influence on activity at highly specialized synapses. It is also possible that the significant interaction of synaptic vesicle components with $\beta 2 *-n A C h R s$ indicates the presence of $\alpha 4 \beta 2 *-n A C h R$-mediated neurotransmitter release process from perisynaptic sites, similar to what has been proposed for $\alpha 7$ and $\alpha 3 *$ nAChRs in the chick ciliary ganglion (Coggan et al., 2005). Interestingly, the degree of interaction between syntaxin $1 \mathrm{~A}$ and $\beta 2 *-n A C h R s$ was reduced in human cortical tissue from nicotine users, raising the possibility that long-term nicotine use promotes a functional reorganization of presynaptic nAChR signaling complexes. The family of 14-3-3 isoforms have multiple functions (for review, see Yaffe, 2002), including acting as chaperones and adaptors that mediate complex protein-protein interactions, and have been shown to facilitate nAChR trafficking and assembly of $\alpha 3 *$ nAChRs at postsynaptic sites in the ciliary ganglion (Rosenberg et al., 2008). The current finding showing that $14-3-3 \zeta$ interacts with $\beta 2 *-n A C h R s$ suggests that adapter protein interactions are critical determinants of trafficking and functional regulation of nAChRs on both presynaptic and postsynaptic plasma membranes and that these interactions are likely to be context specific. Nicotine use may also induce restructuring of postsynaptic elements of cholinergic synapses, but in this study we did not reliably identify components of larger postsynaptic complexes associated with $\beta 2 *-n A C h R s$. It is possible that in the cortex of both mice and humans, the postsynaptic $\beta 2 *-n A C h R$ interactome is more dynamic and less likely to survive the conditions used for isolating $n A C h R s$ in this study; additional studies using methods for enriching and isolating nAChRs from specific subcellular neuronal compartments is necessary to address this question.

The proteoglycan agrin, which contributes to the orchestration of nAChR clustering at the neuromuscular junction (NMJ; Wallace et al., 1991), has also been identified as an inhibitor of $\alpha 3$-containing $\mathrm{Na} / \mathrm{K}$ ATPases (Hilgenberg et al., 2006). We identified $\alpha 3 \mathrm{Na} / \mathrm{K}$-ATPase as a 

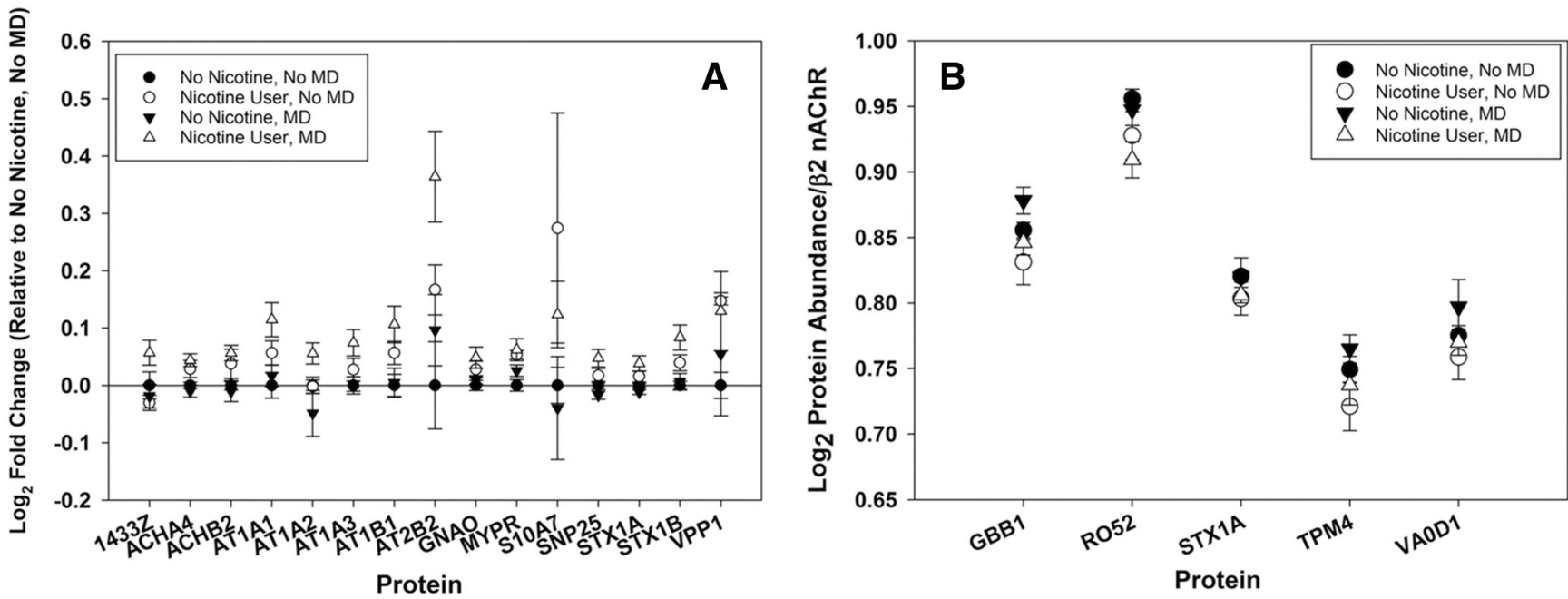

Figure 4. $\boldsymbol{A}$, Representation of the log2-normalized fold change in $\beta 2 *-n A C h R$-associated proteins in human temporal cortex relative to the non-nicotine, non-MD group average. The graph shows nAChR-associated proteins whose expression is significantly impacted by nicotine, MD, or an interaction, according to GLM. Group means above zero are upregulated by nicotine exposure, indicating that as $\mathrm{nAChR}$ levels increase, so do the levels of those proteins. Increases in excess of the log2 fold change for the $\alpha 4-$ and $\beta 2-n A C h R$ subunits indicate a superstoichiometric shift. $\boldsymbol{B}$, Log2 protein abundance normalized to within-sample $\beta 2-n A C h R$ protein content for five proteins that showed a significant shift with nicotine use. Normalization demonstrates the change in protein expression per molecule of the nAChR $\beta 2$-subunit in human cortical samples. For these samples, LFQ proteomics allows the comparison of protein levels, even when the variation in total abundance across treatments is small. Normalization to an internal standard in each condition ( $\beta 2$-subunit levels) allows the measurement of more discrete changes than are apparent from fold change estimates.

Table 8. $\beta 2 *-n A C h R$-associated proteins that show a significant effect of nicotine use on their "per- $\beta 2$ " abundance from human temporal cortex

\begin{tabular}{lllll}
\hline Accession & Description & Significant effect & $F$ & $p$ Value \\
GBB1_HUMAN & Guanine nucleotide-binding protein G(I)/G(S)/G(T) subunit $\beta 1$ & Nicotine & $F_{(1,17)}=10.085$ & 0.007 \\
RO52_HUMAN & E3 ubiquitin-protein ligase TRIM21 & Nicotine & $F_{(1,17)}=5.676$ & 0.031 \\
STX1A_HUMAN & Syntaxin-1A & Nicotine & $F_{(1,17)}=5.375$ & 0.036 \\
TPM4_HUMAN & Tropomyosin $\alpha 4$-chain & Nicotine & $F_{(1,17)}=5.911$ & 0.029 \\
VAOD1_HUMAN & V-type proton ATPase subunit d 1 & Nicotine & $F_{(1,17)}=6.700$ & 0.021
\end{tabular}

These proteins have abundance indices that correlate significantly with levels of $\beta 2-n A C h R$, but the effect of nicotine is apparent only when protein content is normalized to total $\beta 2-n A C h R$ levels, suggesting that their expression does not track linearly with increases in nAChR due to nicotine-induced upregulation and likely represent limiting interactions.

$\beta 2 *$-nAChR-interacting protein from both human and mouse cortical tissues. Its abundance was upregulated along with the $\beta 2 *-n A C h R$ subunit in the human samples with nicotine treatment, as evidenced by the similar ratio of $\alpha 3 \mathrm{Na} / \mathrm{K}$-ATPase/ $\beta 2$-nAChR levels across treatment groups. This parallel increase suggests that aspects of presynaptic neuronal excitability are changed by longterm nicotine treatment beyond the alterations in excitation due to prolonged $\mathrm{nAChR}$ desensitization or other mechanisms of agonist-induced functional changes. An additional link between altered Na/K-ATPase activity and mood disorder is found in the Myshkin mouse model, which harbors a loss-of-function mutation in the $\alpha 3 \mathrm{Na} / \mathrm{K}$ ATPase and exhibits behavioral hallmarks of the manic phase of bipolar disorder that are responsive to traditional pharmacotherapies (valproate, lithium) as well as inhibitors of downstream signaling linked to $\alpha 3 \mathrm{Na} / \mathrm{K}-\mathrm{ATP}$ ase (Kirshenbaum et al., 2011). Postsynaptic nAChRs at the NMJ copurify with the $\alpha 2 \mathrm{Na} / \mathrm{K}-\mathrm{ATP} a \mathrm{se}$ subunit (Heiny et al., 2010; Talsma et al., 2014), and we observe signifi- cant correlation here of $\alpha 2-\mathrm{Na} / \mathrm{K}$ ATPase abundance with $\beta 2 *-n A C h R s$. Genetic risk variants for mood disorders have been found in the $\mathrm{Na} / \mathrm{K}$ ATPase $\alpha 2-$ and $\alpha 3$-loci (Talsma et al., 2014), highlighting the potential functional interactions between nAChRs and Na/K-ATPases in the CNS that may also impact lifetime risk for developing mood disorders. The fact that we observe $\alpha 4 \beta 2 *$-nAChRs associated with $\mathrm{Na} / \mathrm{K}-\mathrm{ATP}$ ase subunits as well as SNARE complex machinery and other mediators of synaptic activity leads us to consider that presynaptic nAChRs may exist as part of a core activity complex with substantial homology to what has been shown to exist postsynaptically at the NMJ (Heiny et al., 2010; Talsma et al., 2014). Further experiments and fine-detailed structural analysis of presynaptic nAChR scaffolds in the CNS will, it is hoped, add to this concept of conserved cholinergic regulation via novel functions of proteins previously unknown as functional regulators of nAChRs.

Another specific $\beta 2$-interactor of interest for additional study is the protein TRIM21, an E3 ubiquitin ligase with 
roles in cell cycle progression and immune signaling (Wada and Kamitani, 2006). Muscle-type nAChR turnover is at least partially dependent on the targeted autophagy of ubiquitinated receptors (Khan et al., 2014), and the role of the ubiquitin-proteasome system in the trafficking and stability of $\alpha 3 *$ nAChRs has been shown in both cell lines (Rezvani et al., 2010) and rodent neurons (Teng et al., 2015). Different E3 ubiquitin ligases were determined to be critical mediators of the selective degradation of ubiquitinylated muscle and $\alpha 3 *$ nAChR subtypes in the previous studies (TRIM63 and CHIP, respectively); our identification of TRIM21 as a $\beta 2 *-n A C h R$-associated E3 ubiquitin ligase in human cortical neurons indicates that future studies are warranted to determine whether it is a specific regulator of $\alpha 4 \beta 2 *-n A C h R$ turnover.

A recent publication presents a hypothesis that nAChRs, including $\beta 2 *-n A C h R$, may possess a structural motif that promotes functional interaction with $G \alpha$ subunits of the heterotrimeric G-protein complex (Kabbani et al., 2013). Earlier studies using proteomic methods to interrogate $\beta 2$-nAChR subunit interactions identified $\mathrm{G} \alpha$ subunits as a reliable associated protein in mouse brain tissue lysate (Kabbani et al., 2007). Here we show that $\beta 2 *-n A C h R s$ from human cortical tissue also associate with $\mathrm{G} \alpha$ subunits (particularly, the $\mathrm{G} \alpha$ o subtype), and that nicotine use significantly affects their abundance index across sample groups. Whether this change in $\mathrm{G} \alpha_{\mathrm{o}}$ interaction with $\beta 2 *-n A C h R s$ is functionally relevant to the physiological response to short-term or long-term nicotine use remains to be elucidated, but our results supporting the earlier discovery that a $\beta 2-G \alpha$ interaction is taking place provides considerable support for additional studies aimed at dissecting the roles of metabotropic signaling via nAChR ion channels.

Of the identified proteins, only two, 14-3-3 $\zeta$ and ATP1A2, showed a significant nicotine $\times$ mood disorder interaction. As noted above, the Na/K ATPase is critically involved in neuronal energetics and at the presynaptic terminal and variants in the ATPase have been associated with mood disorders (Talsma et al., 2014). In contrast, 14-3-3 proteins are involved in chaperoning nAChRs from the endoplasmic reticulum to the cell surface, and this chaperone function is regulated by protein phosphorylation (Jeanclos et al., 2001). The significant nicotine $x$ mood disorder interaction in the association of these proteins with $\beta 2 *-\mathrm{nAChRs}$ may therefore suggest that $\mathrm{nAChR}$ trafficking is altered differentially by nicotine exposure in individuals with mood disorders. This is an intriguing hypothesis that can be evaluated in future studies.

Our data have identified several proteins involved in the regulation of neuronal excitation and neurotransmitter exocytosis that are proximally associated with nAChRs in humans and mice, and are significantly affected by physiological conditions known to impact the expression of nAChRs themselves. While mood disorders have been demonstrated to involve significant contributions from cholinergic components, the impacts of smoking status on nAChR expression as well as the expression of interacting proteins appears to be a much more powerful perturbation. It is possible that different mood disorders (i.e., bipolar disorder vs major depression vs general anxiety disorder) are also representative of distinct entities with respect to cholinergic dysfunction that would benefit from additional exploration of discrete changes in the nAChR-associated proteome. These results indicate that the regulation of $n A C h R s$ and other membrane signaling complexes in skeletal muscle share core regulatory and functional interactions with $\beta 2 *$-neuronal nAChRs, albeit with different proteins that serve functionally similar roles. This study shows that proteomic methods are a powerful tool to identify proteins associated with nAChRs. Proteomic strategies were different for the human and mouse $\beta 2-n A C h R$-interacting protein identifications, and, despite obvious technical distinctions, strengths, and weaknesses, remarkably conserved protein complexes were found to be associated with assembled receptors. Additional proteomic studies aimed at a finer dissection of cell type-specific nAChR interactions may identify more targets that regulate and are regulated by $\mathrm{nAChR}$ activity to provide additional mechanistic insight into the contribution of cholinergic dysfunction in neurological disorders.

\section{References}

Barik J, Wonnacott S (2009) Molecular and cellular mechanisms of action of nicotine in the CNS. Handb Exp Pharmacol 173-207.

Breese CR, Marks MJ, Logel J, Adams CE, Sullivan B, Collins AC, Leonard S (1997) Effect of smoking history on [3H]nicotine binding in human postmortem brain. J Pharmacol Exp Ther 282:7-13. Medline

Buisson, B., Bertrand, D (2001) Chronic exposure to nicotine upregulates the human $\alpha 4 / \beta 2$ nicotinic acetylcholine receptor function. $J$ Neurosci 21:1819-1829. Medline

Caldarone BJ, Harrist A, Cleary MA, Beech RD, King SL, Picciotto MR (2004) High-affinity nicotinic acetylcholine receptors are required for antidepressant effects of amitriptyline on behavior and hippocampal cell proliferation. Biol Psychiatry 56:657-664. CrossRef

Coggan JS, Bartol TM, Esquenazi E, Stiles JR, Lamont S, Martone ME, Berg DK, Ellisman MH, Sejnowski TJ (2005) Evidence for ectopic neurotransmission at a neuronal synapse. Science 309: 446-451. CrossRef Medline

Dilsaver SC (1986) Pathophysiology of "cholinoceptor supersensitivity" in affective disorders. Biol Psychiatry 21:813-829. Medline

Dilsaver SC, Coffman JA (1989) Cholinergic hypothesis of depression: a reappraisal. J Clin Psychopharmacol 9:173-179. Medline

Esterlis I, Hannestad JO, Bois F, Sewell RA, Tyndale RF, Seibyl JP, Picciotto MR, Laruelle M, Carson RE, Cosgrove KP (2013) Imaging changes in synaptic acetylcholine availability in living human subjects. J Nucl Med 54:78-82. CrossRef Medline

Govind AP, Walsh H, Green WN (2012) Nicotine-induced upregulation of native neuronal nicotinic receptors is caused by multiple mechanisms. J Neurosci 32:2227-2238. CrossRef

Hannestad JO, Cosgrove KP, DellaGioia NF, Perkins E, Bois F, Bhagwagar Z, Seibyl JP, McClure-Begley TD, Picciotto MR, Esterlis I (2013) Changes in the cholinergic system between bipolar depression and euthymia as measured with [123I]5IA single photon emission computed tomography. Biol Psychiatry 74:768-776. CrossRef

Hatchell PC, Collins AC (1980) The influence of genotype and sex on behavioral sensitivity to nicotine in mice. Psychopharmacology (Berl) 71:45-49. Medline

Heiny JA, Kravtsova VV, Mandel F, Radzyukevich TL, Benziane B, Prokofiev AV, Pedersen SE, Chibalin AV, Krivoi II (2010) The nicotinic acetylcholine receptor and the Na,K-ATPase alpha2 isoform 
interact to regulate membrane electrogenesis in skeletal muscle. $\mathrm{J}$ Biol Chem 285:28614-28626. CrossRef

Hilgenberg LG, Su H, Gu H, O'Dowd DK, Smith MA (2006) Alpha3Na+/K+-ATPase is a neuronal receptor for agrin. Cell 125: 359-369. CrossRef Medline

Huang da W, Sherman BT, Lempicki RA (2009) Systematic and integrative analysis of large gene lists using DAVID bioinformatics resources. Nat Protoc 4:44-57. CrossRef Medline

Jacob P 3rd, Yu L, Duan M, Ramos L, Yturralde O, Benowitz NL (2011) Determination of the nicotine metabolites cotinine and trans-3'-hydroxycotinine in biologic fluids of smokers and nonsmokers using liquid chromatography-tandem mass spectrometry: biomarkers for tobacco smoke exposure and for phenotyping cytochrome P450 2A6 activity. J Chromatogr B Analyt Technol Biomed Life Sci 879:267-276.

Jeanclos EM, Lin L, Treuil MW, Rao J, DeCoster MA, Anand R, (2001) The chaperone protein 14-3-3eta interacts with the nicotinic acetylcholine receptor alpha 4 subunit. Evidence for a dynamic role in subunit stabilization. J Biol Chem 276:28281-28290. CrossRef

Kabbani N, Woll MP, Levenson R, Lindstrom JM, Changeux JP (2007) Intracellular complexes of the beta2 subunit of the nicotinic acetylcholine receptor in brain identified by proteomics. Proc Natl Acad Sci U S A 104, 20570-20575. CrossRef Medline

Kabbani N, Nordman JC, Corgiat BA, Veltri DP, Shehu A, Seymour VA, Adams DJ (2013) Are nicotinic acetylcholine receptors coupled to $G$ proteins? Bioessays 35:1025-1034. CrossRef Medline

Khan MM, Strack S, Wild F, Hanashima A, Gasch A, Brohm K, Reischl M, Carnio S, Labeit D, Sandri M, Labeit S, Rudolf R (2014) Role of autophagy, SQSTM1, SH3GLB1, and TRIM63 in the turnover of nicotinic acetylcholine receptors. Autophagy 10:123-136. CrossRef Medline

Kirshenbaum GS, Clapcote SJ, Duffy S, Burgess CR, Petersen J, Jarowek KJ, Yucel YH, Cortez MA, Snead OC 3rd, Vilsen B, Peever JH, Ralph MR, Roder JC (2011) Mania-like behavior induced by genetic dysfunction of the neuron-specific $\mathrm{Na}+, \mathrm{K}+-$-ATPase $\alpha 3$ sodium pump. Proc Natl Acad Sci U S A 108:18144-18149. CrossRef

Laje RP, Berman JA, Glassman AH (2001) Depression and nicotine: preclinical and clinical evidence for common mechanisms. Curr Psychiatry Rep 3:470-474. Medline

Latosinska A, Vougas K, Makridakis M, Klein J, Mullen W, Abbas M, Stravodimos K, Katafigiotis I, Merseburger AS, Zoidakis J, Mischak H, Vlahou A, Jankowski V (2015) Comparative analysis of label-free and 8-Plex iTRAQ approach for quantitative tissue proteomic analysis. PLoS One 10:e0137048 CrossRef Medline

Lerman C, Audrain J, Orleans CT, Boyd R, Gold K, Main D, Caporaso N (1996) Investigation of mechanisms linking depressed mood to nicotine dependence. Addict Behav 21:9-19. Medline

Lowry OH, Rosebrough NJ, Farr AL, Randall RJ (1951) Protein measurement with the Folin phenol reagent. J Biol Chem 193:265275.

Marks MJ, Pauly JR, Gross SD, Deneris ES, Hermans-Borgmeyer I, Heinemann SF, Collins AC (1992) Nicotine binding and nicotinic receptor subunit RNA after chronic nicotine treatment. J Neurosci 12:2765-2784.

Marks MJ, McClure-Begley TD, Whiteaker P, Salminen O, Brown RW, Cooper J, Collins AC, Lindstrom JM (2011) Increased nicotinic acetylcholine receptor protein underlies chronic nicotineinduced up-regulation of nicotinic agonist binding sites in mouse brain. J Pharmacol Exp Ther 337:187-200. CrossRef

Massadeh AM, Gharaibeh AA, Omari KW (2009) A single-step extraction method for the determination of nicotine and cotinine in Jordanian smokers' blood and urine samples by RP-HPLC and GC-MS. J Chromatogr Sci 47:170-177. Medline

McClure-Begley TD, Stone KL, Marks MJ, Grady SR, Colangelo CM, Lindstrom JM, Picciotto MR (2013) Exploring the nicotinic acetylcholine receptor-associated proteome with ITRAQ and transgenic mice. Genomics Proteomics Bioinformatics 11:207-218. CrossRef

Mellacheruvu D, Wright Z, Couzens AL, Lambert JP, St-Denis NA, Li T, Miteva YV, Hauri S, Sardiu ME, Low TY, Halim VA, Bagshaw RD,
Hubner NC, Al-Hakim A, Bouchard A, Faubert D, Fermin D, Dunham WH, Goudreault M, Lin ZY, et al (2013) The CRAPome: a contaminant repository for affinity purification-mass spectrometry data. Nat Methods 10:730-736. CrossRef

Melroy-Greif WE, Stitzel JA, Ehringer MA (2016) Nicotinic acetylcholine receptors: upregulation, age-related effects and associations with drug use. Genes Brain Behav 15:89-107. CrossRef

Mineur YS, Picciotto MR (2009) Biological basis for the co-morbidity between smoking and mood disorders. J Dual Diagn 5:122-130. CrossRef Medline

Mineur YS, Picciotto MR (2010) Nicotine receptors and depression: revisiting and revising the cholinergic hypothesis. Trends Pharmacol Sci 31:580-586. CrossRef Medline

Mineur YS, Somenzi O, Picciotto MR (2007) Cytisine, a partial agonist of high-affinity nicotinic acetylcholine receptors, has antidepressant-like properties in male C57BL/6J mice. Neuropharmacology 52:1256-1262. CrossRef Medline

Mineur YS, Eibl C, Young G, Kochevar C, Papke RL, Gündisch D, Picciotto MR (2009) Cytisine-based nicotinic partial agonists as novel antidepressant compounds. J Pharmacol Exp Ther 329:377386. CrossRef Medline

Mineur YS, Obayemi A, Wigestrand MB, Fote GM, Calarco CA, Li AM, Picciotto MR (2013) Cholinergic signaling in the hippocampus regulates social stress resilience and anxiety- and depression-like behavior. Proc Natl Acad Sci U S A 110:3573-3578. CrossRef Medline

Nashmi R, Xiao C, Deshpande P, McKinney S, Grady SR, Whiteaker P, Huang Q, McClure-Begley T, Lindstrom JM, Labarca C, Collins AC, Marks MJ, Lester HA (2007) Chronic nicotine cell specifically upregulates functional alpha $4 *$ nicotinic receptors: basis for both tolerance in midbrain and enhanced long-term potentiation in perforant path. J Neurosci 27:8202-8218. CrossRef

Philip NS, Carpenter LL, Tyrka AR, Price LH (2010) Nicotinic acetylcholine receptors and depression: a review of the preclinical and clinical literature. Psychopharmacology (Berl) 212:1-12. CrossRef Medline

Picciotto MR, Zoli M, Léna $C$, Bessis $A$, Lallemand $Y$, Le Novère $N$, Vincent P, Pich EM, Brûlet P, Changeux J-P (1995) Abnormal avoidance learning in mice lacking functional high-affinity nicotine receptor in the brain. Nature 374:65-67. CrossRef Medline

Picciotto MR, Zoli M, Rimondini R, Léna C, Marubio LM, Pich EM, Fuxe K, Changeux JP (1998) Acetylcholine receptors containing the beta-2 subunit are involved in the reinforcing properties of nicotine. Nature 391:173-177. CrossRef

Rabenstein RL, Caldarone BJ, Picciotto MR (2006) The nicotinic antagonist mecamylamine has antidepressant-like effects in wildtype but not beta2- or alpha7-nicotinic acetylcholine receptor subunit knockout mice. Psychopharmacology 189:395-401. CrossRef Medline

Rezvani K, Teng Y, De Biasi M (2010) The ubiquitin-proteasome system regulates the stability of neuronal nicotinic acetylcholine receptors. J Mol Neurosci 40:177-184. CrossRef

Rosenberg MM, Yang F, Giovanni M, Mohn JL, Temburni MK, Jacob $\mathrm{MH}$ (2008) Adenomatous polyposis coli plays a key role, in vivo, in coordinating assembly of the neuronal nicotinic postsynaptic complex. Mol Cell Neurosci 38:138-152. CrossRef Medline

Ross SA, Wong JY, Clifford JJ, Kinsella A, Massalas, JS, Horne MK, Scheffer IE, Kola I, Waddington JL, Berkovic SF, Drago J (2000) Phenotypic characterization of an alpha 4 neuronal nicotinic acetylcholine receptor subunit knock-out mouse. J Neurosci 20:6431-6441.

Saricicek A, Esterlis I, Maloney KH, Mineur YS, Ruf BM, Muralidharan A, Chen Jl, Cosgrove KP, Kerestes R, Ghose S, Tamminga CA, Pittman B, Bois F, Tamagnan G, Seibyl J, Picciotto MR, Staley JK, Bhagwagar Z (2012) Persistent $\beta 2 *$-nicotinic acetylcholinergic receptor dysfunction in major depressive disorder. Am J Psychiatry 169:851-859. CrossRef

Smits AH, Jansen PW, Poser I, Hyman AA, Vermeulen M (2013) Stoichiometry of chromatin-associated protein complexes revealed by label-free quantitative mass spectrometry-based proteomics. Nucleic Acids Res 41:e28. CrossRef 
Staley JK, Krishnan-Sarin S, Cosgrove KP, Krantzler E, Frohlich E, Perry E, Dubin JA, Estok K, Brenner E, Baldwin RM, Tamagnan GD, Seibyl JP, Jatlow P, Picciotto MR, London ED, O'Malley S, van Dyck CH (2006) Human tobacco smokers in early abstinence have higher levels of beta2* nicotinic acetylcholine receptors than nonsmokers. J Neurosci 26:8707-8714. CrossRef

Talsma AD, Chaves JF, LaMonaca A, Wieczorek ED, Palladino MJ (2014) Genome-wide screen for modifiers of $\mathrm{Na}(+) / \mathrm{K}(+)$ ATPase alleles identifies critical genetic loci. Mol Brain 7:89. CrossRef Medline

Teaktong T, Graham AJ, Johnson M, Court JA, Perry EK (2004) Selective changes in nicotinic acetylcholine receptor subtypes related to tobacco smoking: an immunohistochemical study. Neuropathol Appl Neurobiol 30:243-254. CrossRef

Teng Y, Rezvani K, De Biasi M (2015) UBXN2A regulates nicotinic receptor degradation by modulating the $\mathrm{E} 3$ ligase activity of $\mathrm{CHIP}$. Biochem Pharmacol 97:518-530. CrossRef Medline
Wada K, Kamitani T (2006) Autoantigen Ro52 is an E3 ubiquitin ligase. Biochem Biophys Res Commun 339:415-421. CrossRef

Wallace BG, Qu Z, Huganir RL (1991) Agrin induces phosphorylation of the nicotinic acetylcholine receptor. Neuron 6:869-878. Medline

Whiteaker P, Jimenez M, McIntosh JM, Collins AC, Marks MJ (2000) Identification of a novel nicotinic binding site in mouse brain using [125I]-epibatidine. Br J Pharmacol 131:729-739.

Wiese S, Reidegeld KA, Meyer HE, Warscheid B (2007) Protein labeling by iTRAQ: a new tool for quantitative mass spectrometry in proteome research. Proteomics 7:340-350. CrossRef Medline

Yaffe MB (2002) How do 14-3-3 proteins work?-Gatekeeper phosphorylation and the molecular anvil hypothesis. FEBS Lett 513:5357. Medline

Zoli M, Léna C, Picciotto MR, Changeux J-P (1998) Identification of four classes of brain nicotinic receptors using beta 2-mutant mice. J Neurosci 18:4461-4472. Medline 